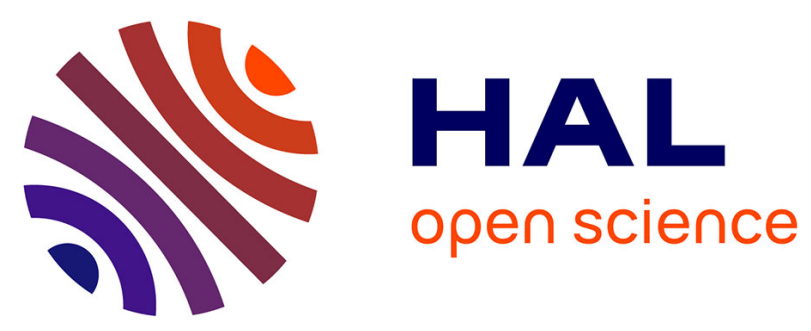

\title{
Characterization of catchment behaviour and rainfall selection for flash flood hydrological model calibration: catchments of the eastern Pyrenees
}

Pierre-André Garambois, Hélène Roux, Kévin Larnier, David Labat, Denis Dartus

\section{To cite this version:}

Pierre-André Garambois, Hélène Roux, Kévin Larnier, David Labat, Denis Dartus. Characterization of catchment behaviour and rainfall selection for flash flood hydrological model calibration: catchments of the eastern Pyrenees. Hydrological Sciences Journal, 2015, vol. 60 ( $\mathrm{n}^{\circ} 3$ ), pp. 424-447. 10.1080/02626667.2014.909596 . hal-01166473

\section{HAL Id: hal-01166473 \\ https://hal.science/hal-01166473}

Submitted on 22 Jun 2015

HAL is a multi-disciplinary open access archive for the deposit and dissemination of scientific research documents, whether they are published or not. The documents may come from teaching and research institutions in France or abroad, or from public or private research centers.
L'archive ouverte pluridisciplinaire HAL, est destinée au dépôt et à la diffusion de documents scientifiques de niveau recherche, publiés ou non, émanant des établissements d'enseignement et de recherche français ou étrangers, des laboratoires publics ou privés. 


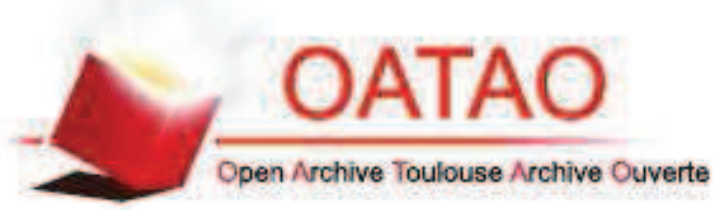

\section{Open Archive TOULOUSE Archive Ouverte (OATAO)}

OATAO is an open access repository that collects the work of Toulouse researchers and makes it freely available over the web where possible.

This is an author-deposited version published in : http://oatao.univ-toulouse.fr/ Eprints ID : 13869

To link to this article : DOI: $10.1080 / 02626667.2014 .909596$

URL : http://dx.doi.org/10.1080/02626667.2014.909596

To cite this version : Garambois, Pierre-André and Roux, Hélène and Larnier, Kévin and Labat, David and Dartus, Denis Characterization of catchment behaviour and rainfall selection for flash flood hydrological model calibration: catchments of the eastern Pyrenees. (2015) Hydrological sciences journal, vol. 60 (n 3). pp. 424-447. ISSN 0262-6667

Any correspondance concerning this service should be sent to the repository administrator: staff-oatao@listes-diff.inp-toulouse.fr 


\title{
Characterization of catchment behaviour and rainfall selection for flash flood hydrological model calibration: catchments of the eastern Pyrenees
}

\author{
P.A. Garambois ${ }^{1,2}$, H. Roux ${ }^{1,2}$, K. Larnier ${ }^{1,2}$, D. Labat ${ }^{1,3}$ and D. Dartus ${ }^{1,2}$ \\ ${ }^{1}$ Université de Toulouse, INPT, UPS, IMFT (Institut de Mécanique des Fluides de Toulouse), F-31400 Toulouse, France \\ ${ }^{2}$ CNRS, IMFT, F-31400 Toulouse, France \\ pgarambo@imft.fr
}

${ }^{3}$ Géosciences Environnement Toulouse, Université de Toulouse-CNRS-IRD-OMP, F-31400 Toulouse, France

\begin{abstract}
Accurate flash flood prediction depends heavily on rainfall data quality and knowledge of catchment behaviour. A methodology based on global sensitivity analysis and hydrological similarity is proposed to analyse flash storm-flood events with a mechanistic model. The behaviour of medium-sized catchments is identified in terms of rainfall-runoff conservation. On the basis of this shared behaviour, rainfall products with questionable quantitative precipitation estimation (QPE) are excluded. This facilitates selection of rainfall inputs for calibration, whereas it can be difficult to choose between two rainfall products by direct comparison. A substantial database of 43 flood events on 11 catchment areas was studied. Nash-Sutcliffe efficiencies for this dataset are around 0.9 in calibration and 0.7 in validation for flash flood simulation in $250-\mathrm{km}^{2}$ catchments with selected QPE. The resulting calibration framework and qualification of possible losses for different bedrock types are also interesting bases for flash flood prediction at ungauged locations.
\end{abstract}

Key words flash floods; global sensitivity analysis; catchment behaviour; QPE; hydrological model calibration; regionalization; bedrock loss

Caractérisation de comportements de bassins versants et sélection de pluies pour la calibration de modèles hydrologiques dans le cas de crues éclair : bassins de l'est des Pyrénées

Résumé La précision des prévisions de crues éclair dépend largement de la qualité des données de pluie et de la connaissance du comportement des bassins versants. Une méthodologie basée sur de l'analyse de sensibilité globale et des similarités hydrologiques est proposée afin d'analyser des évènements de crues éclair à l'aide d'un modèle pluie débit mécaniste. Le comportement de bassins versants de taille moyenne est identifié en termes de conservation du volume d'eau entre la pluie et le débit. A partir d'un comportement hydrologique, les produits de pluie présentant des estimations quantitatives de précipitation (EQP) douteuses sont exclus. Ainsi, la sélection de données de pluie pour la calage est facilitée alors qu'il peut être difficile de choisir un produit de pluie plutôt qu'un autre par une comparaison directe. Une base de données conséquente et composée de 43 évènements de crues sur 11 bassins versants a été étudiée. Les performances (Nash) sont de l'ordre de 0,9 en calage et de 0,7 en validation pour des crues éclair survenues sur des bassins de $250 \mathrm{~km}^{2}$ et modélisées à l'aide d'EQP sélectionnées. La méthode de caage et l'identification de pertes potentielles vers le socle rocheux sont des bases intéressantes pour la prévision de crues éclair sur des bassins non jaugés.

Mots clefs crue éclair ; analyse de sensibilité globale ; comportement hydrologique de bassin versant ; EQP ; calage de modèle hydrologique ; régionalisation ; perte vers le socle rocheux

\section{INTRODUCTION: PROBLEM FRAMEWORK}

Like the storms that cause them, flash floods are very variable and nonlinear phenomena in time and space, with the result that understanding and anticipating flash flood genesis is far from straightforward. Flash floods are generally triggered by intense and localized storms, and water depth in the drainage network can reach peak levels in a few minutes or a few hours (Georgakakos 1992). Monitoring flash 
floods is particularly difficult (Borga et al. 2008), as conventional measurement networks monitoring rainfall and river discharges cannot sample effectively due to problems of scale (Creutin and Borga 2003). That is why hydrological forecasts focus increasingly on remote sensing techniques, such as radar (Krajewski and Smith 2002), high-resolution hydrometeorological prediction models (Seity et al. 2011, Vincendon et al. 2010, 2011), knowledge of climatic antecedents of a catchment or region and initialization of event models (Tramblay et al. 2010, Roux et al. 2011). Taking into account the uncertainty due to the model structure itself or to spatio-temporal rainfall is recognized as important in hydrological modelling (Kirstetter et al. 2010, Delrieu et al. 2014). As highlighted by Looper and Vieux (2012), flood prediction accuracy is linked to the quality of rainfall estimates and forecasts. The robustness of rainfall-runoff models might be increased and knowledge of uncertainty might be improved by the availability, the anteriority and the quality of hydrometeorological time series, and, in several cases, by their space-time resolution.

Estimated precipitation can be considered as one of the most important inputs required for hydrological prediction. Rainfall distribution and amount determine surface hydrological processes and therefore catchment response dynamics. An adequate characterization of rainfall input is fundamental for success in rainfall-runoff modelling: no model, however well founded in physical theory or empirically justified by past performance, can produce accurate runoff predictions forced by inaccurate rainfall data (e.g. Beven 2002, Moulin et al. 2009).

Although radar-based weather coverage has increased considerably over the last two decades enabling high-resolution spatial and temporal measurements of rainfall, quantitative precipitation estimation (QPE) still presents difficulties due to the limitations of radar measurements. Radar QPE therefore still currently relies strongly on gauge measurements.

An important question is how many raingauges are needed to get a correct QPE and to model error, or what radar-to-gauge ratio is required? In the case of catchment hydrology the underlying question is: does the proportion of the rainfall measured by the raingauge network explain most of the hydrological response, and with what accuracy? Indeed the significance of in situ measurements can be directly affected by catchment rainfall space-time dynamics (Viglione et al. 2010, Zoccatelli et al. 2011). For instance, the speed and direction of movement of rain cells seem to exert a strong control on the hydrological response of an arid catchment (Yakir and Morin 2011).

However, rainfall estimation errors, like other sources of uncertainty, can be mainly compensated by hydrological model parameter values often determined through a calibration process. Bárdossy and Das (2008) show that the semi-distributed HBV model using different rainfall measurement networks needs to be recalibrated. Specifically they state that calibration of the model with relatively sparse rainfall data leads to good performance with dense precipitation measurement, while the model calibrated on dense precipitation information fails on sparse data. There are several studies of Mediterranean flash floods at the regional scale in the literature. Ayral et al. (2007), with the ALTHAIR model, and Le Lay and Saulnier (2007), with the event-based TOPMODEL approach, tested different levels of sophistication in the regionalization of inputs and model parameters. Ayral et al. (2007) obtained a systematic overestimate of peak discharge and a satisfactory simulation of the time of the peak when the model was used with spatially homogeneous parameters. Le Lay and Saulnier (2007) show that the efficiency of the model significantly increases when the spatial variability of rainfall is taken into account. Nevertheless, for some catchments the performance failures remain unexplained. Tramblay et al. (2011) used soil moisture initialization with SIM data (SAFRAN-ISBA-MODCOU; Habets et al. 2008) and show the benefit of using spatial radar to measure rainfall on the Gardon d'Anduze catchment $\left(545 \mathrm{~km}^{2}\right)$ in the Cévennes region, France, particularly for the largest flood events. Versini (2012) shows that in the Gard region, France, the predictive power of a road submersion system in cases of flash floods is affected by rainfall uncertainty which drastically drops for lead times exceeding two hours. The effects of uncertainty in the rainfall forecast are highlighted by a recent study in the Besos River basin, Catalonia, Spain (Quintero et al. 2012). However, little information can be found in the literature about the calibration of flash flood models and the problem of rainfall uncertainty.

The problem of rainfall uncertainty is particularly crucial when attempting to develop flash flood regionalization methodologies, especially on fastresponding catchments involving several difficult problems, such as structural, parametric or data uncertainties. Regionalization of model parameters 
to ungauged catchments is generally performed on the basis of knowledge acquired from modelling on gauged catchments (Merz and Blöschl 2004, Wagener et al. 2004, Blöschl 2005). Different approaches may give considerably different results, particularly if unusual conditions prevail, e.g. regarding soil, geology, or climatology (Weingartner et al. 2003). For this reason, it is particularly important to understand catchment response through a sensitivity analysis of model parameters. Sensitivity analysis that assesses the impact of model parameters on the output is indeed a convenient tool for investigating model behaviour and particularly the importance of certain choices of parameterization within the model. It is possible to explore high-dimensional parameter space and some studies show the usefulness of sensitivity analysis for hydrological model improvement (Andréassian et al. 2001, Oudin et al. 2006, Tang et al. 2007, Pushpalatha et al. 2011), or to better understand model behaviour with respect to inputs such as precipitation (Xu et al. 2006, Meselhe et al. 2009).

Hydrological models are characterized by complex response surfaces due to the mathematical formulation used to describe the rainfall-runoff phenomenon. It can therefore be difficult to determine optimal parameter combinations given multiple convergence zones, anisotropic curving, or singular points responsible for discontinuities of derivatives (Johnston and Pilgrim 1976, Duan et al. 1992). This poses the problem of local extrema for both calibration and sensitivity analysis. In this context, global sensitivity analysis methods, unlike local ones, have been proposed for examining multiple locations in the physically possible parameter space. Regional sensitivity analysis (RSA) was originally developed by Hornberger and Spear (1981) and later called generalized sensitivity analysis (GSA) by Freer et al. (1996) in the context of environmental modelling to reduce the number of model parameters. This approach is particularly important with the current shift towards distributed hydrological models. In the case of flash flood event modelling, it is indeed interesting to perform an analysis of the sensitivity of model outputs to parameter variations over large ranges. The GSA method is a global approach. It tackles the question of sensitivity by sampling the space of uncertain model inputs (parametric uncertainty is usually considered) in order to enable the conditioning of model predictions on available observations using a likelihood measure (Beven and Binley 1992).
Understanding the sources of uncertainty is currently a central question in hydrology. This can be achieved by various methods, of which formal Bayesian methods (Kuczera and Parent 1998) and the generalized likelihood uncertainty estimation (GLUE) method (Beven and Binley 1992) are the most popular, along with recursive application of GSA for dynamic identifiability analysis (Wagener et al. 2003) or Bayesian total error analysis (Kavetski et al. 2006) for comprehensive calibration and uncertainty estimation. They have been widely discussed with respect to their philosophy and the mathematical rigour on which they rely (Gupta et al. 2003, Beven 2006, Mantovan and Todini 2006, Todini 2007, Beven et al. 2008, Yang et al. 2008, Vrugt et al. 2009, Jin et al. 2010, Yang 2011). These contributions show that results of the GLUE method are notably influenced by threshold values on the cost function and parameter variation ranges (Yang et al. 2008, Yang 2011). In addition, Li et al. (2010) performed a comprehensive evaluation of the parameters and total uncertainty estimated by GLUE and a formal Bayesian approach to quantify the consequences of (a) threshold values or the acceptable sample rate (ASR), and (b) the number of sample simulations on the results of GLUE.

Moreover, the need to define limits of acceptability before model runs when applying the GLUE methodology is highlighted in Beven (2006). For example, limits of acceptability for discharge are defined using an estimated rating curve error at five sites within the Skalka catchment in the Czech Republic, and then relaxed to allow a strong realization effect in predicted flood frequencies (Blazkova and Beven 2009).

In this study we focus on the quality of the rainfall estimate for rainfall-runoff modelling and the selection of calibration events for the regionalization of flash flood models. Indeed for regionalization, a rainfall-runoff model may need to be calibrated on gauged catchments. This raises the questions: How do we select the calibration/validation events? Should all possible events be used? What about the intrinsic quality of the mean areal precipitation for each event and its impact on the estimated values of the parameters? For the catchments of interest in the Mediterranean region, several rainfall products are often available and for most events it is difficult to choose between them using direct comparison of the different rainfall products. This study proposes a methodology using sensitivity analysis of the MARINE rainfall-runoff model, dedicated to flash 
flood analysis and forecasting in the Mediterranean region (Roux et al. 2011). Based on the results of this sensitivity analysis, water conservation controls and simulated runoff coefficients are explored. In particular, cumulative distribution functions of the parameters often show mean catchment behaviours, which help to select flash flood events for model calibration. This enables rainfall products with questionable QPE to be excluded. The aim is to prepare the calibration of catchment parameter sets and reduce the significant uncertainty introduced by rainfall QPE data in the case of flash flood modelling. The chosen catchments possess contrasting physiographic properties, thus helping to provide a holistic understanding of hydrological controls (Gaál et al. 2012).

The present paper is organized as follows. Section 2 is a presentation of the study zone and the catalogue of catchments and events considered, with some characteristics of soils and geology for comparative general sensitivity analysis. Section 3 briefly presents the MARINE model and its hypothesis. Section 4 investigates the influence of different radar or interpolated rainfall products measured with raingauges on model calibration and sensitivities, particularly for soil volume. Section 5 presents catchment parameter sets calculated with a multiple event calibration method, with, for each event selected, the best rainfall products by comparing their respective sensitivities. Finally, Section 6 presents a discussion on modelling performance and the resulting understanding of hydrological processes, regarded as a first essential step towards prediction of flash floods in ungauged catchments.

\section{STUDY ZONE AND CATCHMENT PROPERTIES}

The proximity of the Mediterranean Sea and the steep surrounding topography can promote low level uplifting in an unstable atmosphere, as for example in the Alps and Pyrenees (Davolio et al. 2009, Tarolli et al. 2012). The region of interest is thus fairly frequently affected by intense rainfall, and represents an interesting area for regional studies of flash floods, considering the number of small to medium-sized responding catchments. The dataset for this study is composed of 11 catchments in the foothills of the eastern Pyrenees with areas ranging from 36 to $776 \mathrm{~km}^{2}$ (Fig. 1), representing a significant number of flood events (43) ranging from moderate flood to strong flash flood. The events selected are the strongest flood responses recorded during the period 1980-2011 for the catchments of interest. In order

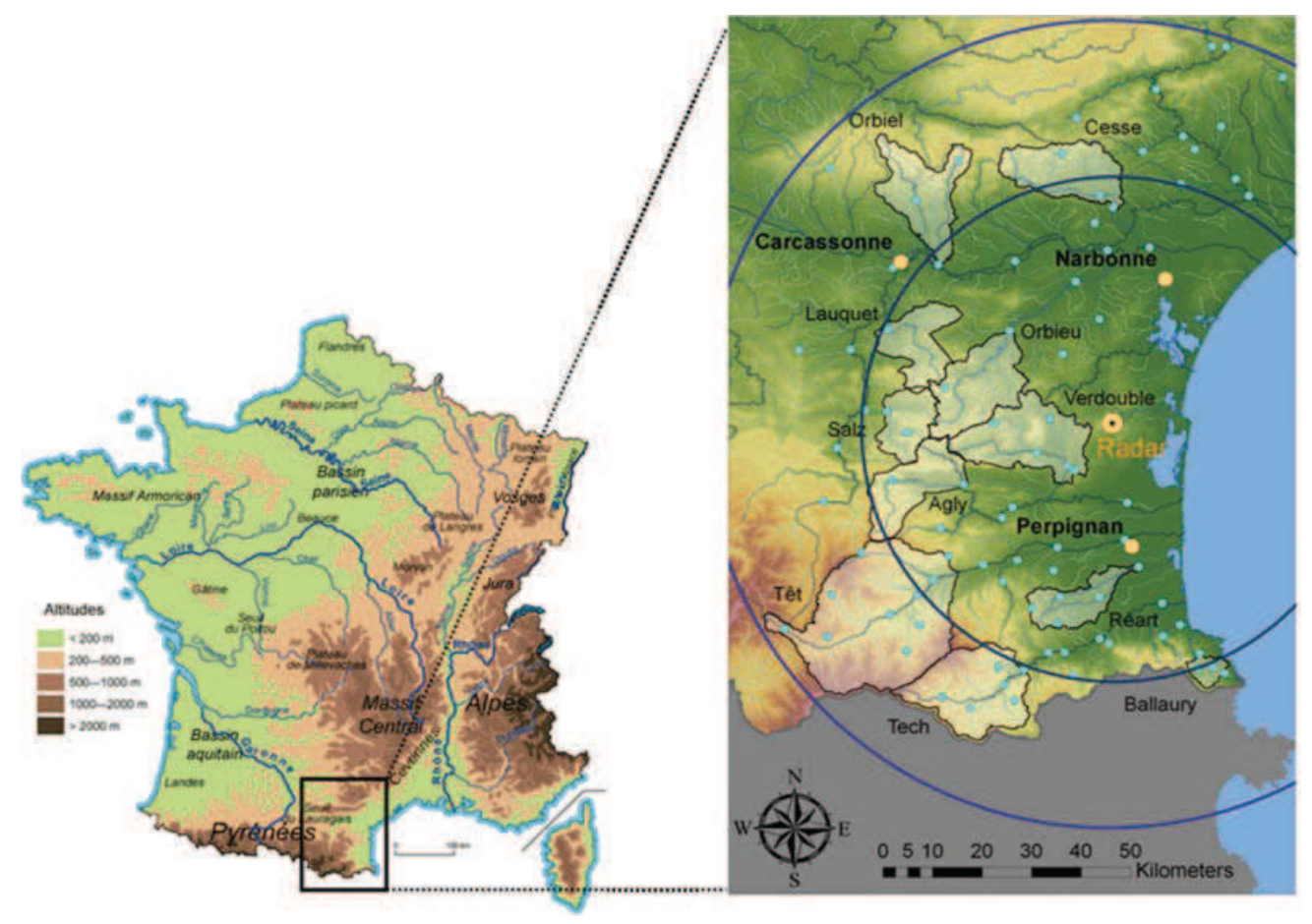

Fig. 1 (Left) Main rivers and mountains of France. (Right) Study zone: Pyrenean foothills and Montagne Noire catchments, showing Opoul radar station, $50-\mathrm{km}$ and $80-\mathrm{km}$ range markers, operational raingauge network, and main cities. 
to study all the strongest flood responses we selected those with specific peak flow over $0.2 \mathrm{~m}^{3} \mathrm{~s}^{-1} \mathrm{~km}^{-2}$ for the selected catchments.

\subsection{Flood-generating rainfall measurements}

The selected catchments are located near the Opoul meteorological radar station (Fig. 1). The dense French raingauge and radar network coverage offers interesting possibilities for capturing the variability of flood-triggering storms (Fig. 1). In this paper we use an operational hourly raingauge network for flood monitoring purposes and data provided by the regional flood forecast service for the Languedoc Roussillon zone, the Service de Prévision des Crues Méditerranée Ouest (SPCMO). We have at least three operational raingauges for the smallest catchments and seven for the largest (Têt) with records going back decades. The average density is two raingauges per $100 \mathrm{~km}^{2}$, with at least one per $100 \mathrm{~km}^{2}$ for the catchments of interest (Fig. 1).

Radar rainfall measurements are available since 2002 with the radar located at Opoul. This radar station belongs to ARAMIS, the operational radar network of Meteo France, which has developed good expertise and algorithms for rainfall estimation from radar reflectivity (Tabary 2007, Tabary et al. 2007). Twenty years of radar hydrology have led to the creation of several radar products with combinations of radar and/or raingauge data for QPE adjustments. In this study we use:

(a) Raingauges interpolated with the Thiessen method (RG_Interp), $\mathrm{d} t=1 \mathrm{~h}$.

(b) Radar rainfalls recalibrated on raingauges (Tabary 2007, Tabary et al. 2007):

- Rainfalls recalibrated by flood forecasters after flood events, available for the west French Mediterranean (SPCMO) and in the Cévennes-Vivarais region from the Service de Prévision des Crues du Grand Delta (SPCGD) (RA_Calibr), $\mathrm{d} t=5 \mathrm{~min}$ and $\mathrm{d} x=1 \mathrm{~km}$;

- A new Meteo France rainfall re-analysis product available for the whole of Metropolitan France before 2010 (RA_ReanH), $\mathrm{d} t=1 \mathrm{~h}$ and $\mathrm{d} x=1 \mathrm{~km}$; and

- PANTHERE rainfalls produced by Meteo France for the whole of Metropolitan France since 2005 (RA_ReanP), $\mathrm{d} t=5 \mathrm{~min}$ and $\mathrm{d} x=1 \mathrm{~km}$.
The RA_ReanP product is considered only after 2010 when RA_ReanH is not available, as the readjustment algorithm and data used might differ between those products. The smallest time resolution of some rainfall products does not exceed $1 \mathrm{~h}$, which is lower than the concentration time of the catchments considered, where the average is about $7 \mathrm{~h}$. Moreover, the results given below might not be strongly affected since they are generally integrated over the duration of an event. The average rainfall duration is $30 \mathrm{~h}$ for this dataset, including a few hours with high rainfall intensities. We do not give a detailed description of the development of rainfall products because our purpose is to study them through hydrological modelling over an entire hydrological region and to take advantage of all the available products.

To describe rainfall products we use first- and second-order moments $\Delta 1, \Delta 2$ integrated over storm duration (Zoccatelli et al. 2011), where $\Delta 1$ describes the distance of the centroid of catchment rainfall with respect to the catchment centroid (average value of the flow distance): a value close to one reflects either a spatially homogeneous rainfall event or rainfall concentrated on the catchment centroid, a value less than one reflects rainfall near the basin outlet, and values greater than one indicate a rainfall distribution closer to the catchment headwaters; and $\Delta 2$ describes the dispersion of rainfall, with a value close to one reflecting uniform rainfall, while values of less than one mean that rainfall has a unimodal trend along the flow distance.

For our dataset, the rainfall products can give different QPE (Fig. 2). Radar range and topography are factors that condition the quality of radar QPE especially for mountainous catchments, as well as the raingauge data used for radar QPE readjustment. From a direct comparison of the different rainfall products for most events, it is difficult to select one rainfall product rather than another. For instance, raingauges might not have seen a significant part of a rainfall field, or masking can directly affect radar QPE. The impact on hydrological simulations can be considerable, for example because of large differences in spatial and temporal distributions of different rainfall products. Rainfall moments integrated over storm duration are reported in Fig. 2 and show the differences of cumulated rainfall, but also the spatial and temporal variability of the different rainfall products available for a given event. 
(a) 455

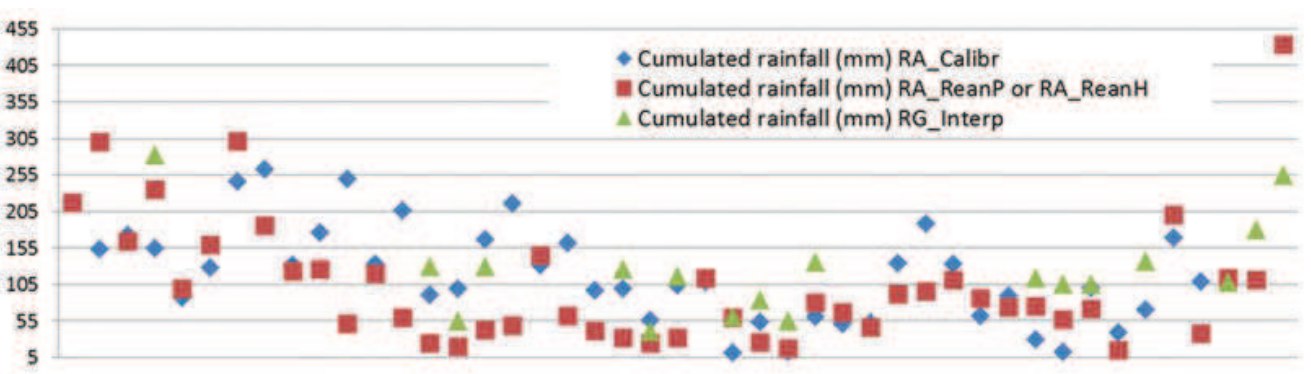

(b)

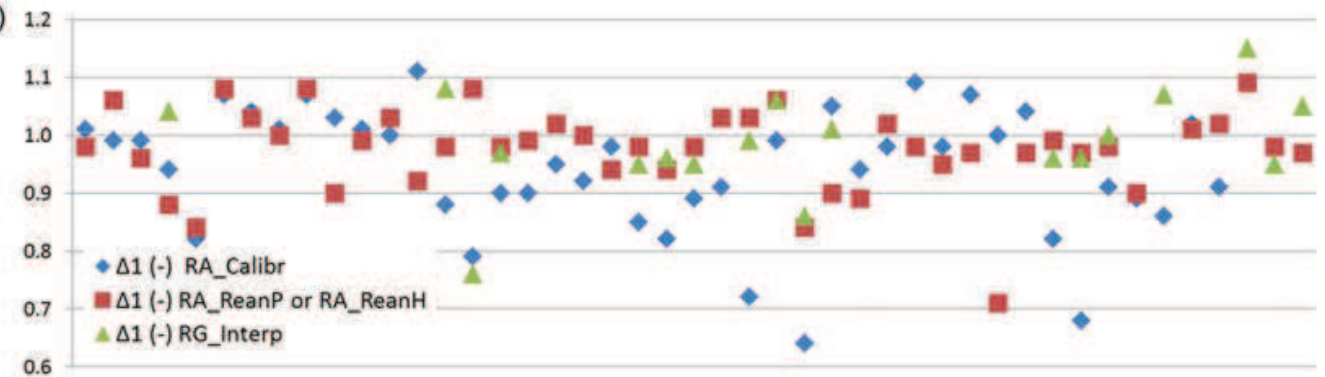

(c) 1.2

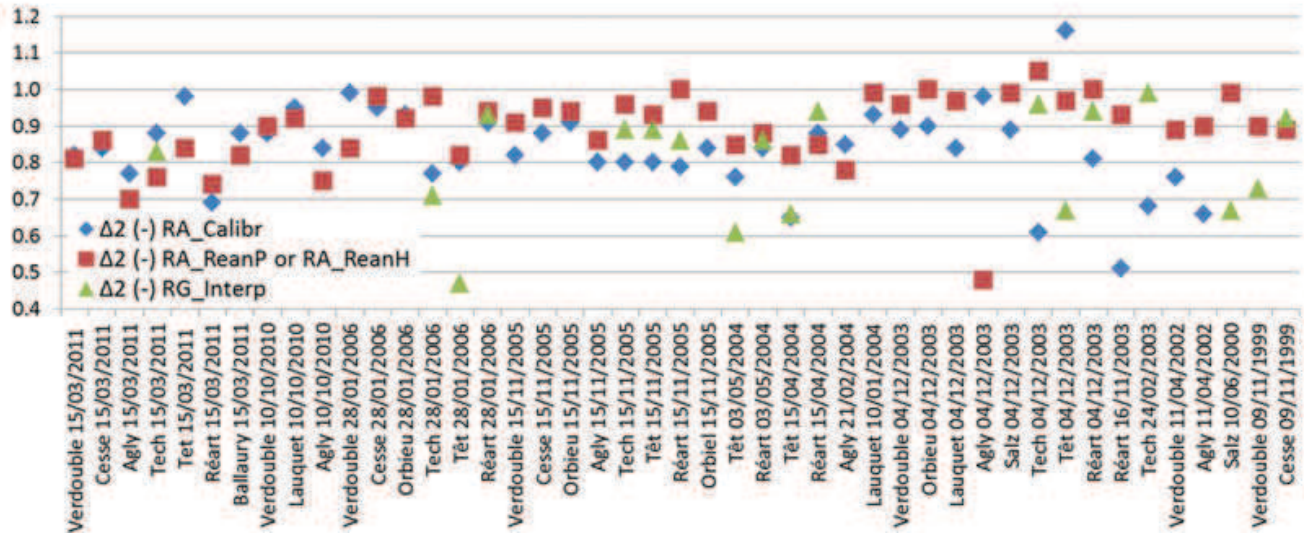

Fig. 2 Characteristics of rainfall fields for the different rainfall products for each catchment-flood considered: (a) cumulated rainfall (mm); (b) first-order moment $\Delta 1$ integrated over storm duration; (c) second-order moment $\Delta 2$ integrated over storm duration.

\subsection{Physiographic characteristics}

The region of interest is located in southwestern France on the Mediterranean coast. The characteristics of the 11 catchments selected for this study are presented in Table 1. Topography is described with a $25 \mathrm{~m}$ resolution digital elevation model (DEM) available from the National Geographic Institute (BD TOPO ${ }^{\circledR}$ C IGN, Paris, 2008). Some of these catchments are tributaries of the River Aude that drains an area of high hills (Corbières) and flows through a narrow valley. Downstream from the city of Carcassonne, the morphology of the valley becomes a broad alluvial valley bordered by the Montagne Noire massif to the north (north and northeast of Carcassonne) and the Corbières hills to the south.
We consider catchments with a sharply marked topography consisting of narrow valleys and steep hill slopes (Fig. 1). Physiographic factors may affect flash flood occurrence in specific catchments by a combination of two main mechanisms: orographic effects that augment precipitation, and topographic effects promoting rapid concentration of stream flow (Costa 1987, O'Connor and Costa 2004). From the Orbieu to the Tech, all the catchments present a strong topographic gradient with an elevation ratio (the height difference divided by the maximum flow path length) ranging between 0.022 and 0.086 (Table 1).

The properties of the superficial layers of the soil such as texture and thickness (Table 1) are extracted from the Languedoc Roussillon soil database 
Table 1 Catchment characteristics; elevation ratio is the max-min elevation divided by the longest flow path. Soil thicknesses are extracted from the BDSol-LR. Concentration time is calculated with the Bransby Williams formula (equation (3)).

\begin{tabular}{|c|c|c|c|c|c|c|c|c|}
\hline Catchment & $\begin{array}{l}\text { Area } \\
\left(\mathrm{km}^{2}\right)\end{array}$ & $\begin{array}{l}\text { Concentration } \\
\text { time (h) (Bransby } \\
\text { Williams) }\end{array}$ & $\begin{array}{l}\text { Height } \\
\text { difference } \\
(\mathrm{m})\end{array}$ & $\begin{array}{l}\text { Maximum } \\
\text { flow path } \\
\text { length }(\mathrm{km})\end{array}$ & $\begin{array}{l}\text { Elevation } \\
\text { ratio }\end{array}$ & $\begin{array}{l}\text { Mean soil } \\
\text { depths (m) } \\
\text { (BD-sol-LR) }\end{array}$ & $\begin{array}{l}\text { Catchment soil } \\
\text { volume }\left(\mathrm{m}^{3}\right) \\
(\mathrm{BD}-\mathrm{sol}-\mathrm{LR})\end{array}$ & $\begin{array}{l}\text { Raingauge density } \\
\text { (raingauges per } \\
100 \mathrm{~km}^{2} \text { ) }\end{array}$ \\
\hline Ballaury & 36 & 2.3 & 890 & 10.4 & 0.086 & 0.21 & $3.59 \mathrm{E}+06$ & 5.6 \\
\hline Salz & 144 & 3.6 & 995 & 17.2 & 0.058 & 0.31 & $4.19 \mathrm{E}+07$ & 1.4 \\
\hline Réart & 145 & 5.8 & 780 & 28.8 & 0.027 & 0.41 & $5.76 \mathrm{E}+07$ & 3.4 \\
\hline Lauquet & 173 & 6.4 & 795 & 29.1 & 0.027 & 0.36 & $6.41 \mathrm{E}+07$ & 1.2 \\
\hline Agly & 216 & 6.4 & 1640 & 33.5 & 0.049 & 0.25 & $5.31 \mathrm{E}+07$ & 1.0 \\
\hline Cesse & 231 & 5.7 & 970 & 36.1 & 0.027 & 0.28 & $6.62 \mathrm{E}+07$ & 1.3 \\
\hline Tech & 250 & 4.4 & 2730 & 34.5 & 0.079 & 0.16 & $5.33 \mathrm{E}+07$ & 2.4 \\
\hline Orbiel & 253 & 5.5 & 1200 & 34.8 & 0.034 & 0.36 & $8.89 \mathrm{E}+07$ & 1.2 \\
\hline Orbieu & 263 & 5.8 & 840 & 37.6 & 0.022 & 0.38 & $9.93 \mathrm{E}+07$ & 1.1 \\
\hline Verdouble & 299 & 5.5 & 915 & 37 & 0.025 & 0.33 & $1.03 \mathrm{E}+08$ & 1.7 \\
\hline Têt & 776 & 7.9 & 2540 & 47.3 & 0.054 & 0.19 & $1.50 \mathrm{E}+08$ & 1.3 \\
\hline
\end{tabular}

(referred to as BDSol-LR) provided by the INRA ${ }^{1}$ (Robbez-Masson et al. 2002) (IGCS ${ }^{2}$ programme, BDSol-LR version 2006). This database gives information on pedological landscapes, which are known as cartographic soil units, at a resolution of $1 / 250000$ (Manus et al. 2009). The importance of soil thickness and hydraulic properties on hydrological processes such as soil saturation, and the determination of what constitutes excess rainfall, is highlighted in the case of flash floods (Braud et al. 2010, Roux et al. 2011). Moreover, the geology of this region is quite complex and bedrock faults or karstic formations can play a role in water conservation or karst outflows triggered by a flood (Nou et al. 2011).

Land cover is very varied in this study area, with moderate slopes occupied by vineyards in the valleys of the River Aude and its tributaries, while the upper slopes are covered by garrigue and scrub. Forest is encountered in the central part of the Montagne Noire and the Pyrenees foothills. Land use maps are derived from remote sensing data (2000 Corine Land Cover: Service de l'Observation et des Statistiques). The substrate of the Aude watershed is mainly composed of silt and sand, developed from limestone and clay-limestone rocks (Fig. 3 and Table 2). Locally, the limestone bedrock is highly karstified, especially in the Montagne Noire (Gaume et al. 2004, Nou et al. 2011). The spatially contrasting bedrock composition can be divided into four groups of catchments with similar bedrocks, most of which are close geographically (Garambois et al. 2014).

\section{DESCRIPTION OF THE MODEL}

The modelling approach chosen for the catchment set is the distributed model MARINE for flash flood forecasting (Roux et al. 2011) with subsurface flow modelling. It takes advantage of distributed forcing and soil spatial properties. The predominant factor considered to give rise to stream discharge is represented by the topography i.e. slope and downhill directions. The model runs on a regular grid of squared cells, $200 \times 200 \mathrm{~m}$. This mesh is more refined than any of those available for rainfall field description, whose cells usually cover $1 \mathrm{~km}^{2}$.

MARINE runs with an adaptive time step (a few seconds to 1 minute) using the Courant-FriedrichsLewy (CFL) condition to reduce calculation time. The model is structured in three main modules (Fig. 4), the first two representing vertical and lateral soil saturation dynamics. The first module separates the precipitation into surface runoff and infiltration using the Green and Ampt model. The second module represents subsurface downhill flow with an approximation of Darcy's law. The third represents the overland flow (over hillslopes and in the drainage network): the transfer function component conveys the excess rainfall to the catchment outlet using the kinematic wave approximation. Both infiltration excess and saturation excess are represented in MARINE. Model parameters are calculated from soil surveys and remote sensing data. Soil thickness and texture maps are derived from the Rawls and Brakensiek definition of soil classes (Rawls and

\footnotetext{
${ }^{1}$ The French National Institute of Agronomical Research.

${ }^{2}$ IGCS: Inventaire, Gestion et Conservation des Sols -voir http://gissol.orleans.inra.fr/.
} 
(a)

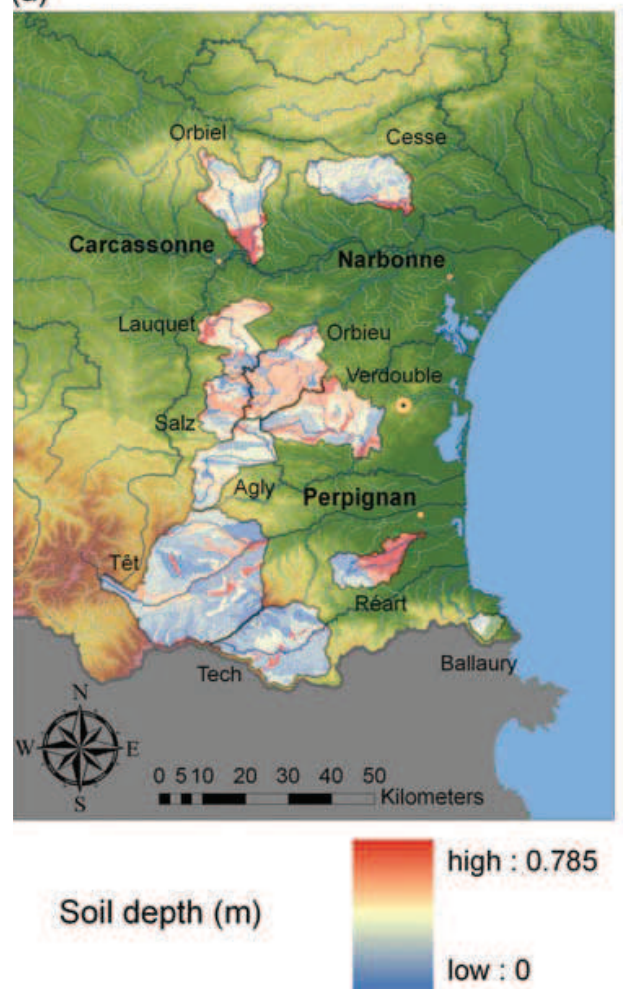

(b)

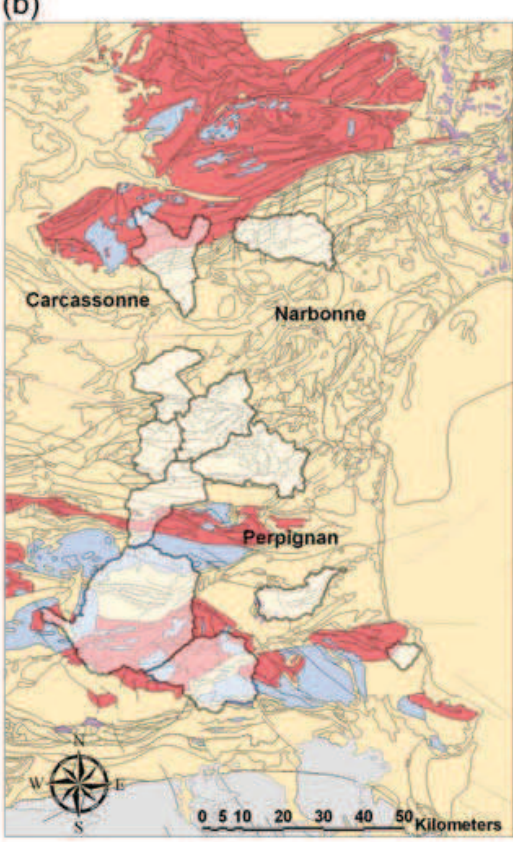

Fig. 3 (a) Soil depth map (source: BD-sols Languedoc Roussillon, INRA), (b) simplified geological formations $($ red $=$ metamorphic, blue $=$ plutonic, yellow $=$ sedimentary, purple $=$ volcanic, grey $=$ no data $)$ and faults (source: $\mathrm{BD}$ Million-Géol, BRGM).

Table 2 Main components of catchment bedrock, referring to Fig. 3, right.

\begin{tabular}{ll}
\hline Catchments & Geology \\
\hline Tech, Têt & - Granite and/or Primary era formations (mainly schist but locally highly karstified limestone) \\
Verdouble, Agly, & - Granite and/or Primary era formations, (top right Verdouble and bottom left Agly on the map) \\
$\quad$ Ballaury & - Mesozoic mainly cretaceous formations (limestone, marl) \\
Salz, Lauquet, & - Primary era formations \\
Orbieu & - Mesozoic, mainly cretaceous formations, \\
& - Tertiary era detritic formations (sand, molasses, conglomerate) \\
Cesse, Orbiel, Réart & - Quaternary alluvia \\
& - Tertianite and/or Primary era detritic formations (sand, molasses,conglomerate) \\
\hline
\end{tabular}

Brakensiek 1985). Soil saturation at the beginning of each event is estimated with SAFRAN-ISBAMODCOU (SIM), a continuous hydrometeorological model (Habets et al. 2008). Evapotranspiration is not represented since the purpose of the model was to simulate individual flood events during which such a process is negligible. Bedrock is not taken into account in the governing equations of the MARINE model since deep percolation is still a poorly understood phenomenon and there are few measurements available with which to constrain a model. But geological maps are useful for analysing the results of flood simulation, especially for comparative hydrology on several physically contrasted catchments. For a complete description of the MARINE model the reader can refer to Roux et al. (2011).

In order to avoid model over-parameterization, the number of parameters to estimate via calibration was kept as low as possible. Spatial patterns of several parameters were derived from soil surveys and a unique correction coefficient was then applied to each parameter map. This approach was chosen for three parameters, namely the distributed saturated 


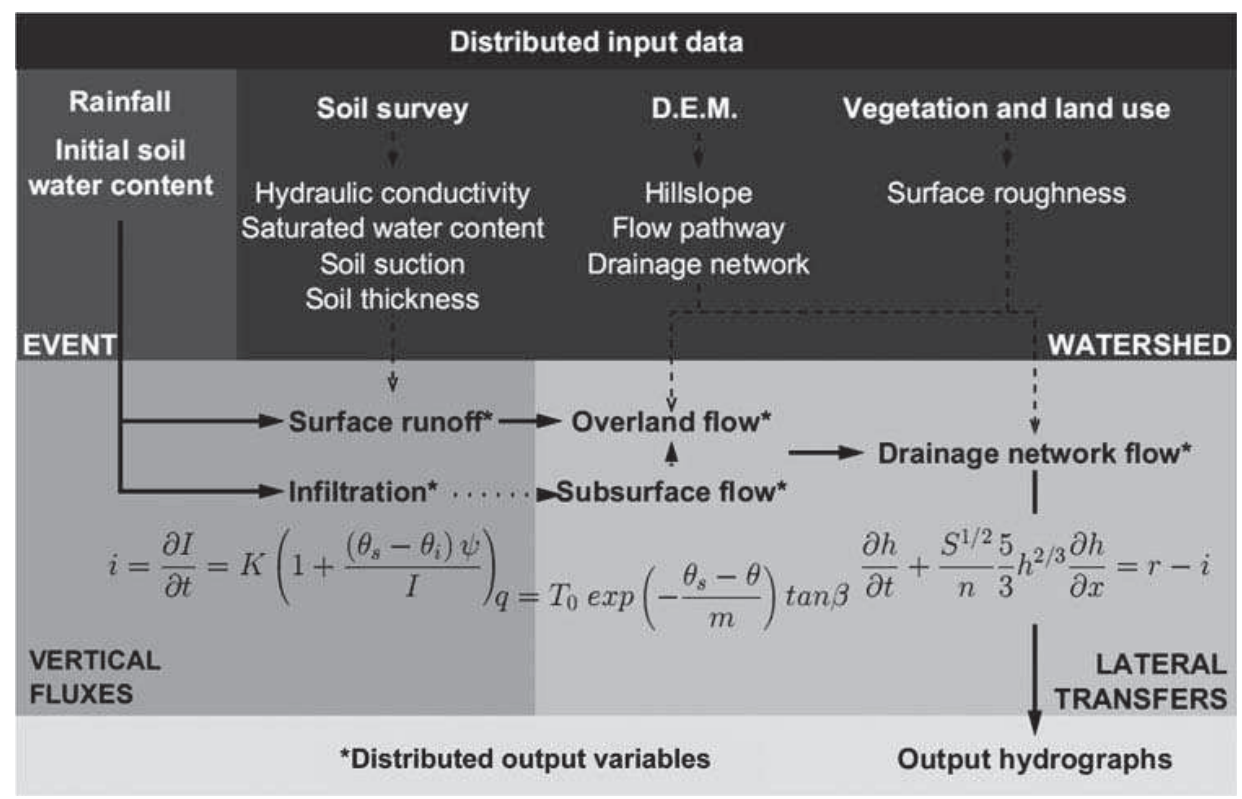

Fig. 4 MARINE model structure, parameters and variables. Green and Ampt infiltration equation: $i$ : infiltration rate ( $\left.\mathrm{m} \mathrm{s}^{-1}\right)$; I: cumulative infiltration $(\mathrm{mm}) ; K$ : saturated hydraulic conductivity $\left(\mathrm{m} \mathrm{s}^{-1}\right) ; \psi$ : soil suction at wetting front (m); $\theta_{s}$ and $\theta_{i}$ : saturated and initial water contents, respectively $\left(\mathrm{m}^{3} \mathrm{~m}^{-3}\right)$. Subsurface flow: $T_{0}$ : local transmissivity of fully saturated soil $\left(\mathrm{m}^{2} \mathrm{~s}^{-1}\right) ; \theta_{s}$ and $\theta$ : saturated and local water contents, respectively $\left(\mathrm{m}^{3} \mathrm{~m}^{-3}\right) ; m$ : transmissivity decay parameter $(-) ; \beta$ : local slope angle (rad). Kinematic wave: $h$ : water depth $(\mathrm{m}) ; t$ : time $(\mathrm{s}) ; u$ : overland flow velocity $\left(\mathrm{m} \mathrm{s}^{-1}\right) ; x$ : space variable $(\mathrm{m}) ; r$ : rainfall rate $\left(\mathrm{m} \mathrm{s}^{-1}\right) ; i$ : infiltration rate $\left(\mathrm{m} \mathrm{s}^{-1}\right) ; S$ : bed slope $\left(\mathrm{m} \mathrm{m}^{-1}\right)$; and $n$ : Manning roughness coefficient $\left(\mathrm{m}^{-1 / 3} \mathrm{~s}\right)$.

hydraulic conductivity $K$, the lateral transmissivity $T_{0}$ and soil thickness $Z$. The calibration procedure consists of estimating three coefficients of correction, one for saturated hydraulic conductivity, named $C_{\mathrm{K}}$, a second for lateral subsurface flow transmissivity, $C_{\mathrm{KSS}}$, and the third for soil thickness, $C_{\mathrm{Z}}$. The Strickler roughness of the main channel $K_{\mathrm{D} 1}$ and the Strickler roughness of the overbank of the drainage network $K_{\mathrm{D} 2}$ are also calibrated. The choice of these parameters follows observations made during a calibration process in the Mediterranean region (Roux et al. 2011). Concerning the subsurface lateral transmissivity $K_{\mathrm{SS}}$, the spatial variability is taken from the vertical hydraulic conductivity map, and the correction coefficient ranges from 100 to 10000 as horizontal flows are considered faster than vertical ones (see Maidment 1992). Calibration parameters and variation range are reported in Table 3 . In practice, initial ranges of parameter values for Monte Carlo sampling are chosen with the intention of exploring a large range of model behaviours. Uniform parameter distributions within their range of variation are mainly used in the absence of prior information.

\section{EVENT MODEL SENSITIVITY ANALYSIS}

\subsection{Objective of the sensitivity analysis}

The aim of this section is to analyse the main characteristics of MARINE model response via a comparison based on the entire dataset for each flood event and for each catchment. The sensitivity analysis of the MARINE model to the five parameters presented

Table 3 Parameter description and variation range for Monte Carlo analysis.

\begin{tabular}{llrr}
\hline & Description & Min & Max \\
\hline$C_{k}$ & Correction coefficient of the hydraulic conductivity (-) & 0.1 & 10 \\
$C_{Z}$ & Correction coefficient of the soil thickness $(-)$ & 0.1 & 10 \\
$C_{\mathrm{KSSs}}$ & Correction coefficient of the soil lateral transmissivity $(-)$ & 100 & 10000 \\
$K_{\mathrm{D} 1}$ & Strickler roughness coefficient of main channel $\left(\mathrm{m}^{1 / 3} \mathrm{~s}^{-1}\right)$ & 1 & 40 \\
$K_{\mathrm{D} 2}$ & Strickler roughness coefficient of the overbank $\left(\mathrm{m}^{1 / 3} \mathrm{~s}^{-1}\right)$ & 1 & 30 \\
\hline
\end{tabular}


above is performed for various hydrological responses within a catchment, and across various physiographic conditions within our catchment dataset. The whole parameter space defined in Table 3 is explored for different physical behaviours. Moreover, different rainfall products are used for several flood events. For each of them, water conservation controls and simulated runoff coefficients are explored using the sensitivity analysis results and particularly the cumulative distribution function of the parameter $C_{\mathrm{Z}}$, which is the main control on water balance. As previously mentioned, the aim of the sensitivity analysis is to prepare for the calibration of catchment parameter sets and reduce the significant uncertainty introduced by rainfall QPE data in flash flood modelling.

The global sensitivity analysis method with cost function considering features characterizing the flood peaks is presented. The impacts of the cost function and the threshold choice on the uncertainty interval and best simulations are shown. Monte Carlo simulations with several rainfall products are presented, with a discussion on water balance modelling. Catchment sensitivity averaged over flood events is then calculated. The most sensitive parameter of the MARINE model on average, $C_{\mathrm{Z}}$, is studied through its posterior distribution functions (pdfs) for each catchment and flood. With respect to this parameter, mean catchment behaviour can be found, enabling comparison and selection of QPE for a flood given the identified catchment behaviour.

\subsection{Sensitivity analysis method: GSA-GLUE}

The generalized sensitivity analysis is performed following the method proposed by Hornberger and Spear (1981). For each flood event (and each rainfall product for a given flood) the sensitivity analysis is performed, based on a 5000-member Monte Carlo sample obtained with a standard random generator. The MARINE model is run with these 5000 parameter sets. Each set of parameter values is then assigned a likelihood of being a simulator of the system, on the basis of the chosen likelihood measure. All model realizations are weighted and ranked on this likelihood scale. On the basis of this likelihood measure, a classification is applied to the model output, resulting in a classification of each model run as behavioural or non-behavioural. The threshold for differentiating between the two classes is a chosen value of the likelihood measure. The cost function and the threshold are determined subjectively, as discussed by Freer et al. (1996).

The separation between the prior and posterior marginal cumulative distributions is subsequently used as a sensitivity measure (Hornberger and Spear 1981): for each parameter $\alpha_{k}$, the distributions relative to behavioural and non-behavioural simulations are plotted. A separation between these distributions indicates that the parameter is important for simulating the behaviour studied. The contrary is not always true. Indeed the distributions may show no separation whereas the parameter $\alpha_{k}$ can be crucial for the simulation because of correlations with other parameters. It is a necessary but not sufficient condition that parameters must be sensitive to be identifiable. Moreover, sample size and sampling variability should be increased systematically to ensure convergence and robustness of the confidence interval respectively.

In the GLUE approach, the likelihood weights associated with the behavioural simulations are applied to their respective model discharges at each time step to give a cumulative distribution of discharges at each time step. Uncertainty quantiles can be calculated from these distributions to represent model uncertainty (Freer et al. 1996).

\subsection{Cost function and threshold value}

The highly nonlinear mathematical formulation of rainfall-runoff transformation produces complex response surfaces for hydrological models. The first step of a sensitivity analysis consists of defining a method that evaluates how well the model conforms to the observed behaviour. But, there is no consensus defining a unique criterion to assess model performance and different objective functions can lead to identification of different parameter combinations (Zin 2002). Besides, we can distinguish methods that use either a partitioning or complete rainfallrunoff records, such as multi-objective optimization (Vrugt et al. 2003). Wagener et al. (2003) propose the concept of dynamic identification with moving windows and, more recently, Choi and Beven (2007) proposed working on sub-periods characterized by similar hydrological behaviour.

This study is focused on a dataset composed of contrasting catchment flood responses (Garambois et al. 2014). The advantages of including several criteria for model performance evaluation, especially for flood modelling, have been pointed out (Aronica et al. 1998, 2002, Werner 2004). The cost function, 
$L_{\mathrm{NP}}$, introduced by Roux et al. (2011) is used, which, in addition to the classical normalized least squares approach, considers features characterizing the flood peak (discharge value and time to peak) (Lee and Singh 1998):

$$
\begin{aligned}
L_{\mathrm{NP}}= & \frac{1}{3} \cdot \mathrm{Nash}+\frac{1}{3} \cdot\left(1-\frac{\left|Q_{s}^{p}-Q_{o}^{p}\right|}{Q_{o}^{p}}\right) \\
& +\frac{1}{3} \cdot\left(1-\frac{\left|T_{s}^{p}-T_{o}^{p}\right|}{T_{o}^{c}}\right)
\end{aligned}
$$

where $Q^{P}{ }_{s}$ and $Q^{P}{ }_{o}$ are respectively the simulated and observed peak runoff, $T^{P}{ }_{S}$ and $T^{P}{ }_{o}$ are respectively the simulated and observed time to peak, and $T^{c}{ }_{0}$ is the time of concentration of the catchment, with

$$
\text { Nash }=1-\frac{\sum_{i=1}^{N_{\text {obs }}}\left(Q_{s}^{t}-Q_{o}^{t}\right)^{2}}{\sum_{i=1}^{N_{\text {obs }}}\left(Q_{o}^{t}-\overline{Q_{o}}\right)^{2}}
$$

where $N_{\text {obs }}$ is the number of observation data, and $Q_{s}$ and $Q_{o}$ are respectively the simulated and the observed runoff. The time of concentration of the catchment is defined using the Bransby formula:

$$
T_{o}^{c}=\frac{21.3 L}{A^{0.1} S^{0.2}}
$$

where $L$ is the channel length (m), $A$ is the watershed area $\left(\mathrm{m}^{2}\right)$ and $S$ is the slope of the linear profile. Discharge data are available at $1-\mathrm{h}$ intervals before 2005 and at 5-min intervals thereafter.

Compared to the Nash criterion (equation (2)) the $L_{\mathrm{NP}}$ cost function grants more importance to peak flow value and timing, which is particularly appropriate for the MARINE model, as it focuses more on flash flood peak flow modelling than on baseflow or recession. It is shown to be the correct compromise for exploring a range of catchment flood behaviours, since it enables simulations to be selected that can be of great use in flood forecasting. The best simulations are shown below.

As explained above, for each flood event and rainfall product, confidence intervals and parameter posterior distribution functions are calculated with the GSA-GLUE method. The influence of the threshold is visible in Fig. 5; a higher value gives a narrower uncertainty interval and a smaller number of behavioural simulations. Moreover, the added value of $L_{\mathrm{NP}}$, with respect to the classical Nash, is shown for this major flood event on the Orbieu: relative error on peak discharge is lower for the best simulations (Fig. 5).

The threshold chosen on $L_{\mathrm{NP}}$ for this method is 0.7 in order to have a sufficient number of behavioural simulations on contrasting catchments. This choice appears reasonable since it ensures (on average 500 behavioural simulations out of 5000 parameter sets) that the number of behavioural simulations ranges from 300 to nearly 1000 for the best-simulated events. For some floods the best simulations can result in $L_{\mathrm{NP}}$ greater than 0.95 . This threshold is relatively high for the $L_{\mathrm{NP}}$ function in flash floods, as attested by the narrow uncertainty interval (Fig. 6). The observations fall within this interval for most of the flood hydrograph. Moreover the uncertainty, especially for peak flow, is below $40 \%$, which is similar to the high flow gauging uncertainty for some catchments and thus the limit of acceptability as defined by Blazkova and Beven (2009). We focus on peak dynamics, according to our cost function, and so it is not surprising if the confidence interval does not fit the observed discharges for the early rising limb or during recession (Fig. 6(a)). It should be remembered that neither baseflow nor recession curves are used in the MARINE model.

\subsection{Event analysis with several rainfall products}

Monte Carlo simulations were performed for each catchment with different rainfall products for some events, when available. A colour scale is applied (Table 4) in order to help visual qualification of performance for event calibration with the different rainfall products (Table 5). Dark green is for the best Monte Carlo simulations for which GSAGLUE is possible with respect to the hypothesis presented before. We can observe that Monte Carlo simulations give good results for all the catchments considered. Indeed, for each catchment, the four rainfall products give at least one flood with the best mark, i.e. (Nash, $\left.L_{\mathrm{NP}}\right)>0.8$ and two above, $\left(\right.$ Nash, $\left.L_{\mathrm{NP}}\right)>0.7$. All the rainfall products can therefore be considered suitable for flash flood modelling purposes on these 11 Mediterranean catchments.

Radar rainfall data seem to improve the possibility of flood modelling, since many of the floods simulated with RA_Calibr give satisfactory 
(a)

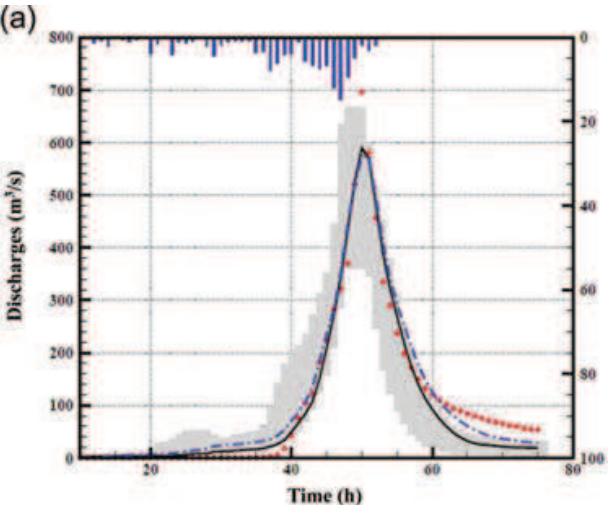

(c)

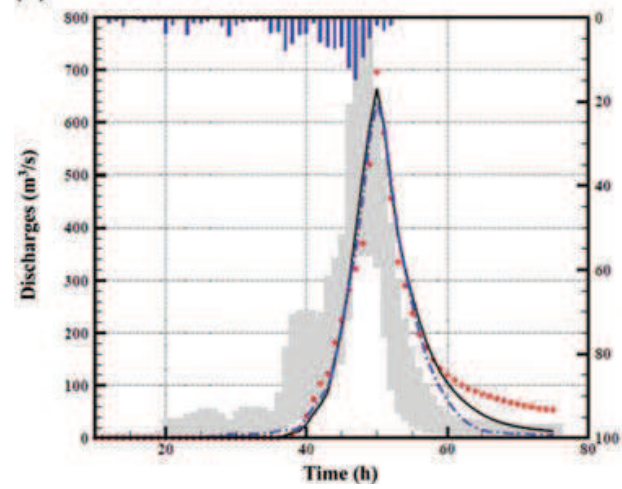

(b)

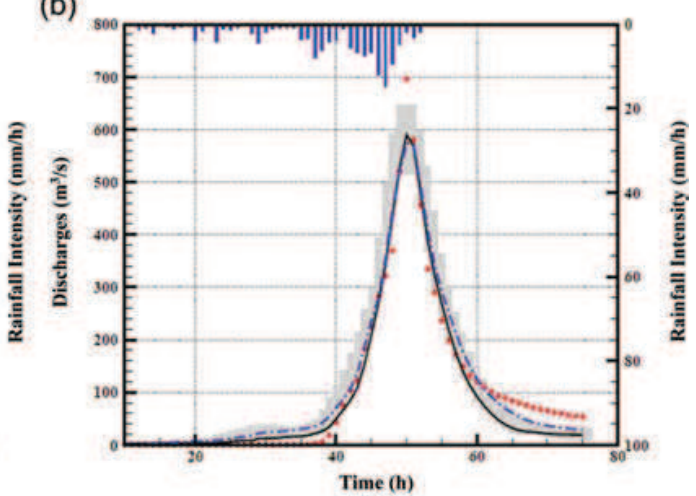

(d)

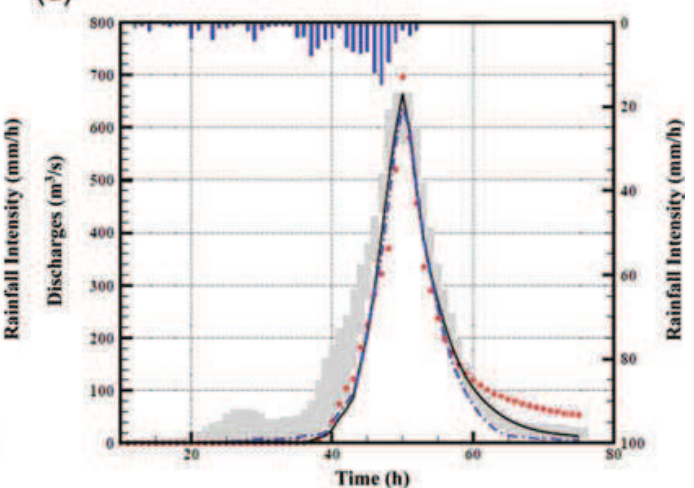

Fig. 5 Observed discharge (dots), best simulations (solid and dashed lines) and uncertainty interval (5-95\% quantiles) for the Orbieu at Lagrasse $\left(263 \mathrm{~km}^{2}\right), 15$ November 2005 flood event performed with RA_Calibr radar rainfall data: (a) Nash threshold $=0.5$; (b) Nash threshold $=0.9$; (c) $L_{\mathrm{NP}}$ threshold $=0.5$; (d) $L_{\mathrm{NP}}$ threshold $=0.9$.

(a)

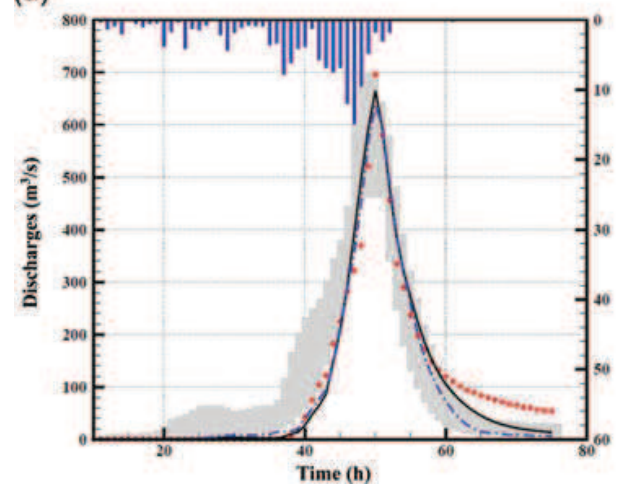

(b)

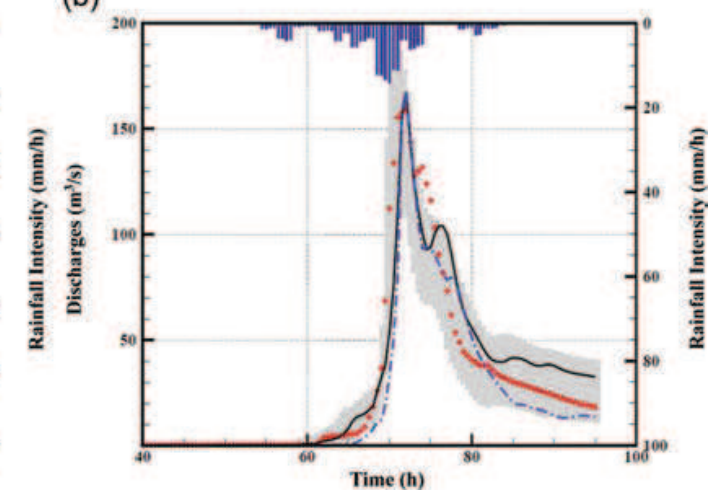

Fig. 6 Observed discharge (dots), two best simulations (solid and dashed lines) and confidence interval for: (a) the Orbieu at Lagrasse $\left(263 \mathrm{~km}^{2}\right) 15$ November 2005 flood event, performed with RA_Calibr radar rainfall data, $L_{\mathrm{NP}}$ threshold $=0.7$, 900 behavioural simulations; (b) the Tech at Pas-du-Loup $\left(250 \mathrm{~km}^{2}\right), 15$ November 2005 flood event, performed with RG_Interp interpolated rainfall data from five raingauges, $L_{\mathrm{NP}}$ threshold $=0.7,480$ behavioural simulations.

performances, with $\left(\mathrm{Nash}, L_{\mathrm{NP}}\right)>0.7$. The two that do not give correct results for RA_Calibr are very low flow events (6 February 2005 for the Orbieu and 10 April 2002 for the Têt), which seems reasonable, as MARINE was originally developed to simulate extreme events. Interpolated raingauges from the dense measurement network give good results (Table 5). It should be noted that even a dense coverage with five raingauges for the Verdouble catchment $\left(299 \mathrm{~km}^{2}\right)$ did not provide good modelling results for the 8 January 1996 and 14 December 1995 events. The rainfall measurement network may not have seen 
Table 4 Efficiency intervals and colour correspondence.

\begin{tabular}{lllllll}
\hline Performance condition for the couple (Nash, LNP) & $>0.8$ & $>0.7$ & $>0.65$ & $>0.5$ & $<0.5$ \\
\hline Colour correspondence
\end{tabular}

Table 5 Event calibration efficiencies. Not all the cells are filled, as a storm-flood event can concern several catchments without affecting the whole dataset. Rainfall products selected with the $\mathrm{C}_{Z}$ pdf similarity method for each catchment since 2002 for calibration $(\checkmark)$, products selected but not used for calibration $(\times), \varnothing$ is for flood events where no rainfall product is chosen.

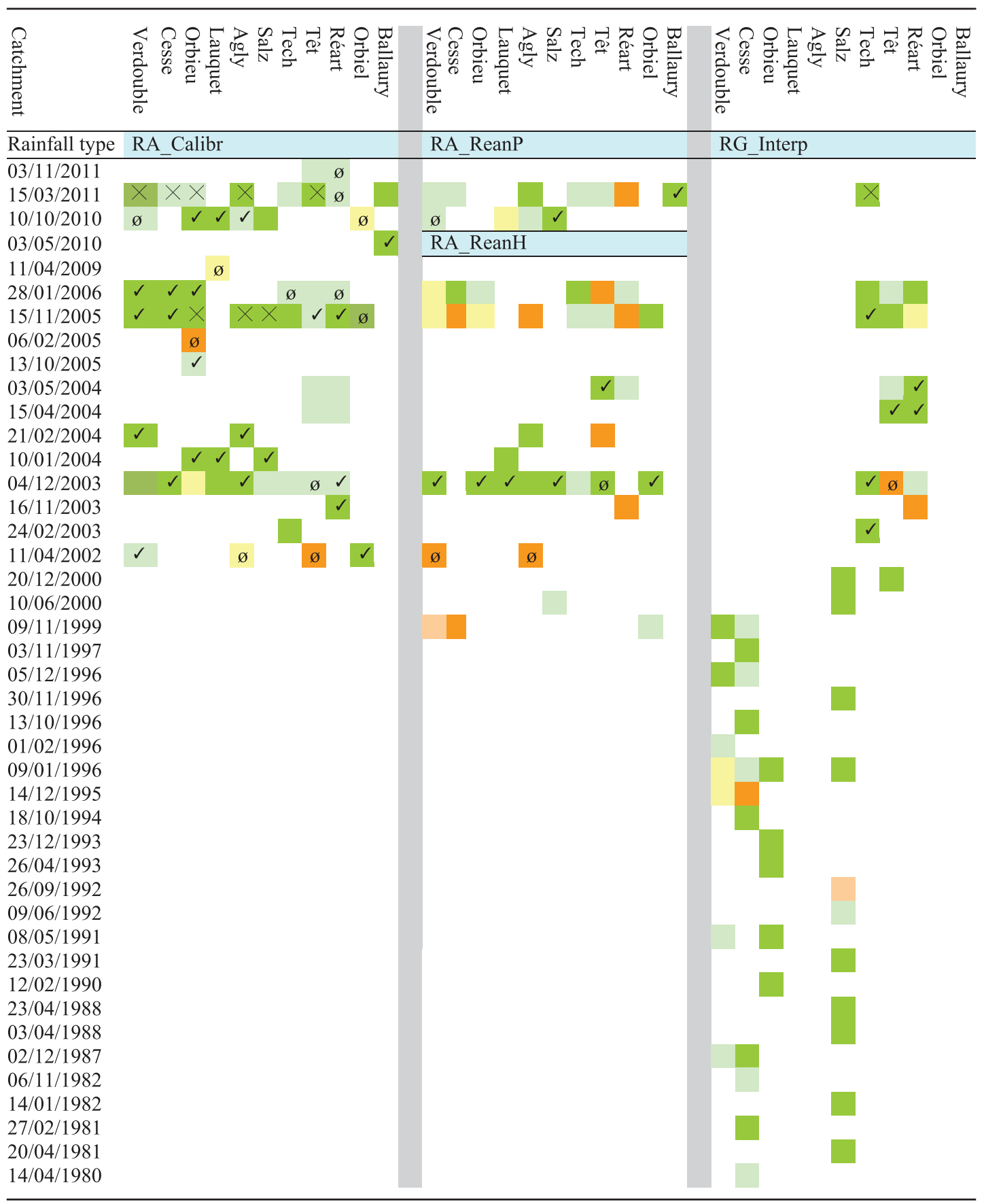


part of rainfall explaining catchment response for these two events.

Simulations in yellow or orange (Table 5), mostly for interpolated raingauges (RG_Interp) or RA_ReanH, are simulations that do not reproduce the observed hydrograph correctly. A low value of $L_{\mathrm{NP}}$ often corresponds with simulations with underestimated peak flow, but still good temporal dynamics and simulated peak time. That is to say for the simulation marked in yellow and orange, the model water balance is not able to reproduce the order of magnitude of peak discharge, and consequently the flood water balance.

Most floods and catchments are correctly modelled with MARINE. Although parameter sets are sampled in relatively wide ranges in order to be able to reproduce different catchment behaviour for several events, all 5000 simulations result in significant underestimates of peak flow. This addresses the question of which phenomenon leads to such an error in water conservation modelling.

In our modelling of rainfall-to-runoff conservation, the four most important sources of error are probably:

(a) QPE under- or over-estimates;

(b) High-flow gauging errors;

(c) model structure and parametric compensation (bedrock loss and evapotranspiration not simulated);

(d) initial soil moisture estimates.

First, the sources of uncertainty (b)-(d) are constant for a given event, so, when considered with different rainfall products, comparisons are possible. We are conscious of problems relating to rating curve quality and initialization errors, but this is not the purpose of this study and it may have a limited impact on the results under our hypothesis. Indeed, most events are of comparable order of magnitude for a given catchment, so we can neglect gauging errors between events. The initialization error inherent in event models is not taken into account since in the MARINE model soil saturation is fixed by the root zone moisture, simulated by the continuous water balance model SIM (Habets et al. 2008) at the beginning of each flood event. The initial soil moisture for the 43 flood events dataset is on average $57.7 \%$ with a rather low standard deviation of $6.6 \%$, so from this variation range its impact on MARINE sensitivity is considered limited.

\subsection{Catchment sensitivity to parameters}

Monte Carlo simulations for each catchment are performed under identical mathematical and physical hypotheses and with the same data types, in order to be able to compare MARINE results and sensitivity between events and catchments. Table 6 shows mean parameter rank for each catchment, obtained by averaging Kolmogorov-Smirnov test values for all the events considered for GSA-GLUE analysis per catchment, with selected rainfalls (Table 7). Mean parameter rank (and thus model sensitivity to flow components) varies as a function of the catchment; $C_{\mathrm{Z}}$, the spatial soil multiplicative constant, is the most sensitive parameter on average followed by $C_{\mathrm{K}}$, whereas $C_{\mathrm{KSS}}$, lateral soil transmissivity, is the least sensitive. No clear tendency appears for $K_{\mathrm{D} 1}$ whose sensitivity depends mainly on catchment properties. No clear trend appears for the overbank roughness $K_{\mathrm{D} 2}$ either, whose rank can vary from 1 to 5 , with an average of 3.

On average, MARINE evaluated with the $L_{\mathrm{NP}}$ cost function is mostly sensitive to $C_{\mathrm{Z}}$ and $C_{\mathrm{K}}$, defining catchment storage capacity and infiltrability. These two sensitive parameters thus indicate that MARINE is mainly sensitive to runoff production dynamics and amounts for flash flood events. The sensitivity of the channel transfer function, represented by main channel roughness and floodplain roughness, is also considerable, whereas subsurface transfer is less sensitive according to the model. Low interactions were found between parameters through covariance analysis with global sensitivity analysis.

Table 6 Mean catchment parameter ranking according to Dmax calculated for each parameter and event, Dmax being the maximum separation between the behavioural and non-behavioural distributions. Mean parameter rank is obtained by averaging each parameter rank for all the catchments.

\begin{tabular}{llllll}
\hline Catchments & $C_{\mathrm{Z}}$ & $C_{\mathrm{K}}$ & $K_{\mathrm{D} 1}$ & $K_{\mathrm{D} 2}$ & $C_{\mathrm{KSS}}$ \\
\hline Tech & 1 & 2 & 4 & 5 & 3 \\
Têt & 1 & 2 & 3 & 5 & 4 \\
Réart & 2 & 1 & 4 & 3 & 5 \\
Verdouble & 3 & 2 & 4 & 1 & 5 \\
Agly & 2 & 1 & 4 & 3 & 5 \\
Salz & 2 & 1 & 2 & 3 & 5 \\
Lauquet & 3 & 4 & 1 & 2 & 5 \\
Orbieu & 3 & 1 & 2 & 4 & 5 \\
Cesse & 1 & 2 & 3 & 5 & 4 \\
Orbiel & 3 & 4 & 2 & 1 & 5 \\
Ballaury & 2 & 5 & 3 & 1 & 4 \\
Mean rank & 2.1 & 2.3 & 2.9 & 3.0 & 4.5 \\
\hline
\end{tabular}


Table 7 Calibrated catchment parameter sets, Nash cost function. Global Nash is the cost function for the whole calibration set, min Ev Nash corresponds to single-event Nash and max EV Nash to single-event maximum Nash for each part of the multiple events hydrograph. Simulated and observed runoff coefficients and efficiencies for validation events.

\begin{tabular}{lccc}
\hline Catchment & Salz & Tech & Verdouble \\
\hline Calibration: & & & \\
$C_{\mathrm{Z}}$ & 0.95 & 4.34 & 1.3 \\
$C_{\mathrm{K}}$ & 20 & 11 & 15 \\
$C_{\mathrm{KSS}}$ & 5595 & 1515 & 4486 \\
$K_{\mathrm{D} 1}$ & 5 & 4.83 & 5 \\
$K_{\mathrm{D} 2}$ & 2.54 & 3.24 & 3.99 \\
Global Nash & 0.89 & 0.9 & 0.88 \\
min Ev Nash & 0.61 & 0.89 & 0.74 \\
max Ev Nash & 0.9 & 0.91 & 0.95 \\
Validation: & & & \\
Event & $20 / 12 / 2000$ & $15 / 03 / 2011$ & $15 / 03 / 2011$ \\
Observed runoff & 0.45 & 0.61 & 0.55 \\
$\quad$ coefficient & & & \\
Simulated runoff & 0.62 & 0.42 & 0.63 \\
$\quad$ coefficient & & & \\
Nash & 0.61 & 0.69 & 0.89 \\
$L_{\mathrm{NP}}$ & 0.7 & 0.74 & 0.87 \\
\hline
\end{tabular}

\subsection{Sensitivity to spatial soil depth and water volume control}

In this section we focus on the spatial soil depth multiplicative constant, $C_{Z}$, which, on average, is seen to be one of the most sensitive parameters of the MARINE model for the 11 catchments. Indeed, $C_{Z}$ is responsible for catchment storage capacity and water balance adjustments: it controls a catchment's soil volume and can compensate runoff volume in a non-negligible but still physical range $\left(C_{Z} \in[0.1,10]\right)$. Roux et al. (2011) previously showed the sensitivity of MARINE to $C_{Z}$ on the Gardon d'Anduze catchment in the Cévennes; this parameter is found to explain $80 \%$ of model output variance when hydrographs peak on several Mediterranean catchments (Garambois et al. 2013). Le Lay and Saulnier (2007) with TOPMODEL, and Braud et al. (2010) with CVN and MARINE models showed that soil depth strongly influences the flash flood response of catchments in the Cévennes. After applying the MARINE model to 11 Mediterranean catchments, we present $C_{Z}$ posterior distribution functions (pdfs) (Figs 7-12). Several events are plotted on one graph in order to compare the pdf shapes, each pdf coming from one Monte Carlo sample. The following interpretations are based on the results of the sensitivity analysis (posterior distribution functions Figs 7-12 summarized in the parameter ranking of Table 6).

According to the Kolmogorov-Smirnov tests performed above, $C_{\mathrm{Z}}$ is the most sensitive parameter for Tech, Têt and Cesse compared to the eight other catchments (Table 6). Concerning Tech and Têt, the shape of the pdfs shows that most of the behavioural simulations are for $C_{Z}$ values greater than 4 , especially for the Têt $\left(C_{Z}>5\right.$, Fig. 7(b)). Sensitivities are similar for these two catchments, which are mainly located on metamorphic terrain.

The Cesse (Fig. 8(a)), Ballaury (Fig. 8(b)), Réart (Fig. 9(a)), Agly (Fig. 10(b)) and Salz (Fig. 12) catchments are also very sensitive to $C_{Z}$, and most of the behavioural simulations are for $C_{Z}$ values of between 1 and 4 . The physiographic and bedrock properties are complex for these catchments: Cesse is highly karstified (Nou et al. 2011) and Réart presents mixed and complex physiographic properties. The Verdouble (Fig. 10(a)), Lauquet (Fig. 11(b)) and Orbieu (Fig. 11(a)) catchments from the Corbières Hills, and the Orbiel catchment (Fig. 9(b)) from the Montagne Noire are less sensitive to $C_{Z}$ than the previous catchments, and overall most of the behavioural simulations are for values of $C_{Z}>1$. The substrates of these basins were mainly developed from sedimentary bedrock (Table 2) overlain by loam and silty loam.

Bedrock loss is not represented in the model. This might be responsible for $C_{\mathrm{Z}}$ values greater than one, as suggested by Castaings et al. (2009) and Roux et al. (2011). The modeller therefore needs to increase soil volume and thus storage capacity, to produce a correct runoff volume for hydrograph formation given a QPE. Bedrock type and alteration might explain the large differences between catchment sensitivity and parameterization for $C_{Z}$.

\subsection{Selection of rainfall QPE with the sensitivity analysis method and mean catchment behaviour}

For each catchment, most of the flood events recorded and simulated with Monte Carlo sampling are eligible for GSA-GLUE (Table 5), (Nash, $L_{\mathrm{NP}}>0.8$ ). In other words, it is possible to find parameter sets producing good performances for one or more rainfall inputs. The final objective is to find correct sets of events/rainfalls for gauged catchment calibration, in order to be able to calibrate the 
(a)

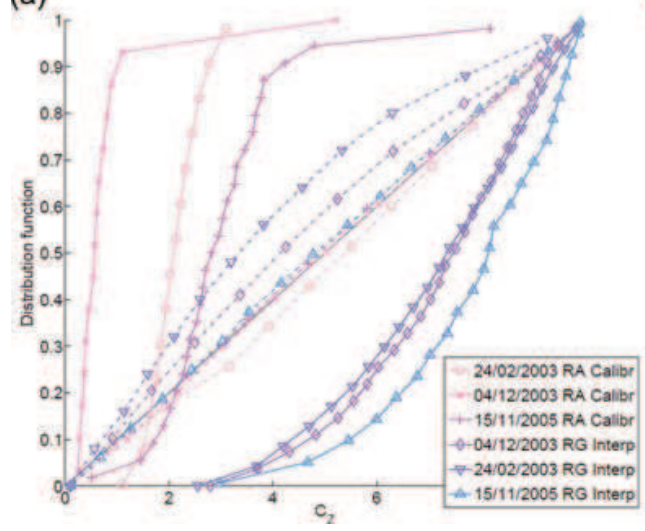

(b)

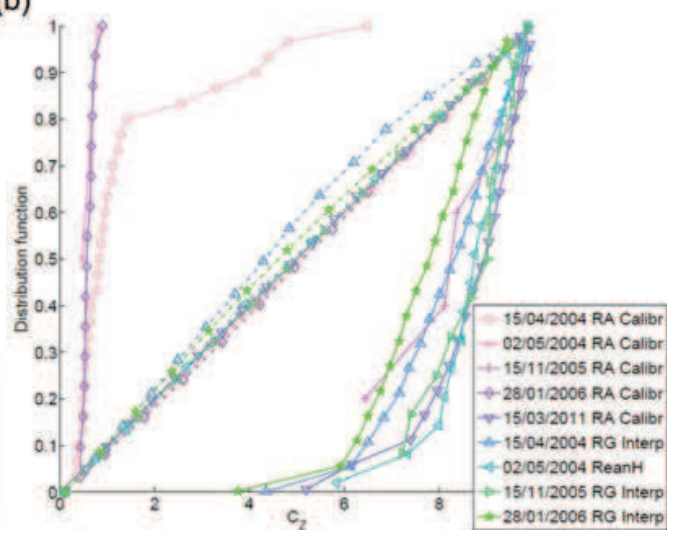

Fig. 7 Event posterior distribution functions: (a) Tech at Pas du Loup, and (b) Têt at Marquixane (solid line: behavioural simulations, dash-dot line: non-behavioural simulations).

(a)

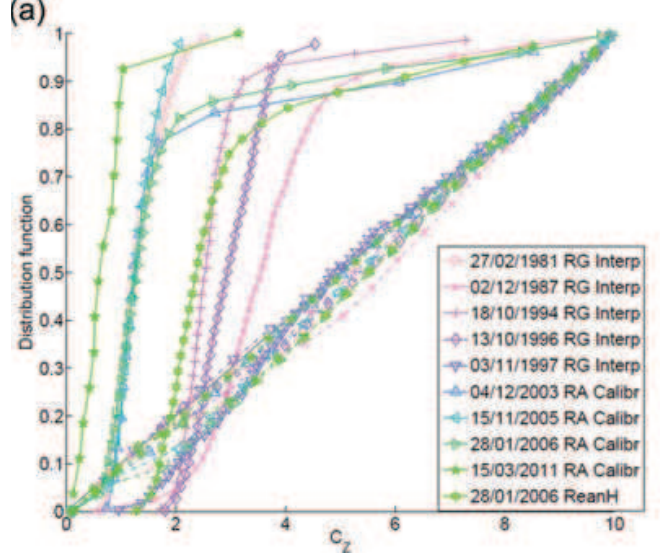

(b)

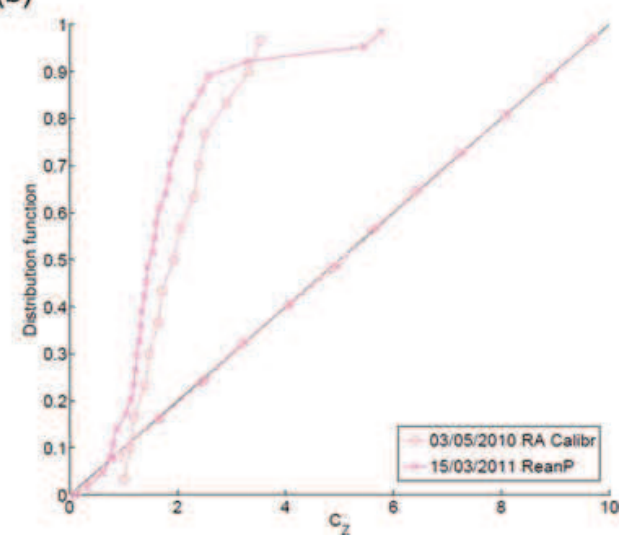

Fig. 8 Event posterior distribution functions: (a) Cesse at Bize-Minervois, and (b) Ballaury at Banyuls (solid line: behavioural simulations, dash-dot line: non-behavioural simulations).

(a)

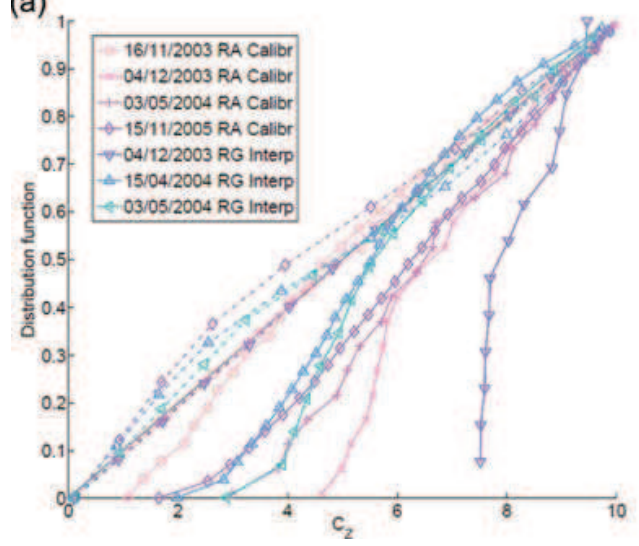

(b)

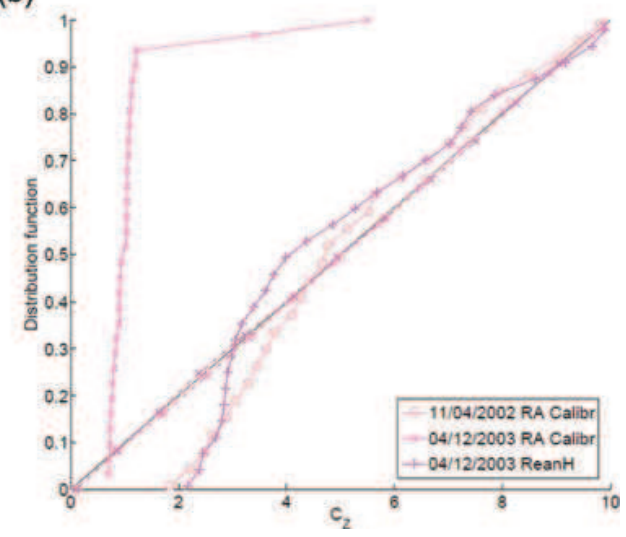

Fig. 9 Event posterior distribution functions: (a) Réart at Salleilles, and (b) Orbiel at Villedubert (solid line: behavioural simulations, dash-dot line: non-behavioural simulations). 
(a)

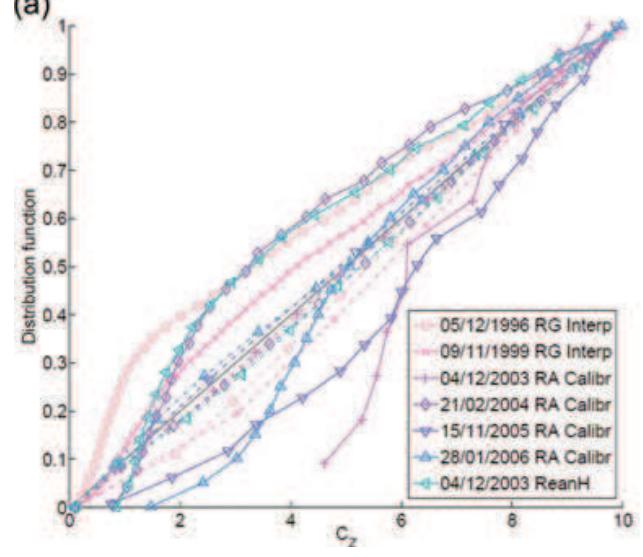

(b)

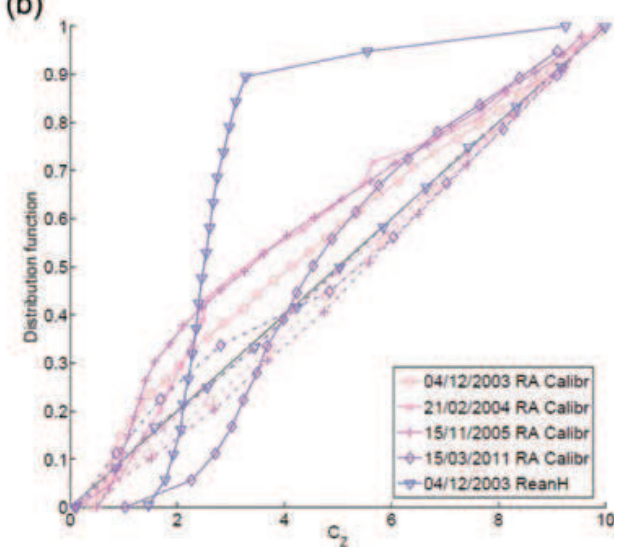

Fig. 10 Event posterior distribution functions: (a) Verdouble at Tautavel, and (b) Agly at St Paul de Fenouillet, (solid line: behavioural simulations, dash-dot line: non-behavioural simulations).
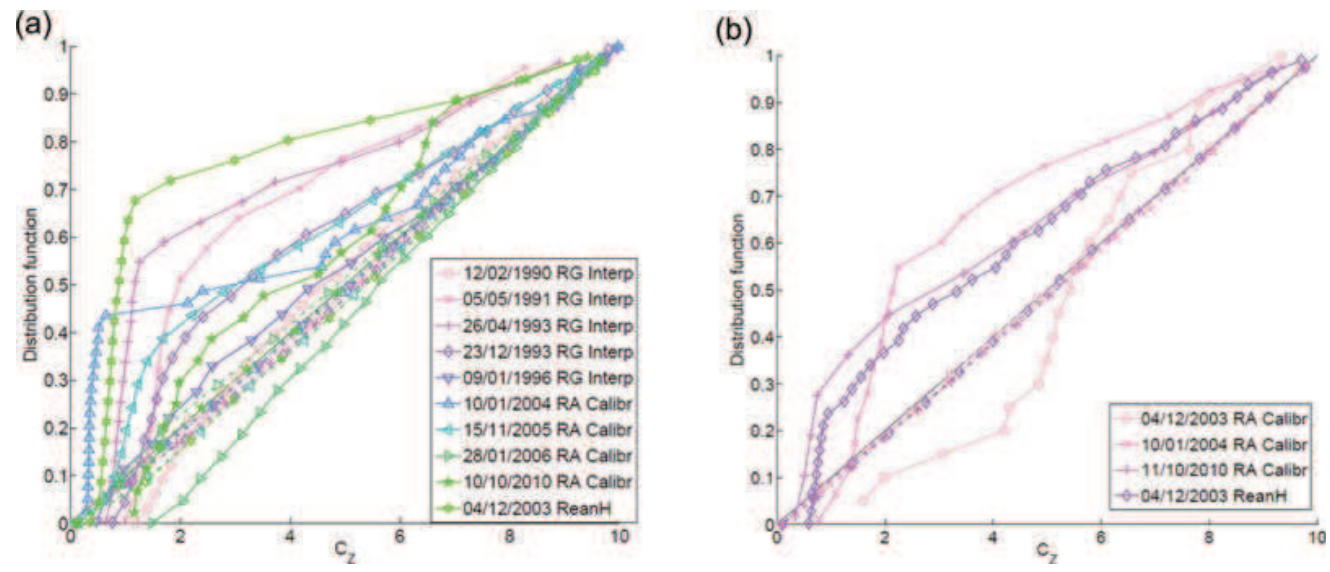

Fig. 11 Event posterior distribution functions: (a) Orbieu at Lagrasse, and (b) Lauquet at St Hilaire (solid line: behavioural simulations, dash-dot line: non-behavioural simulations).

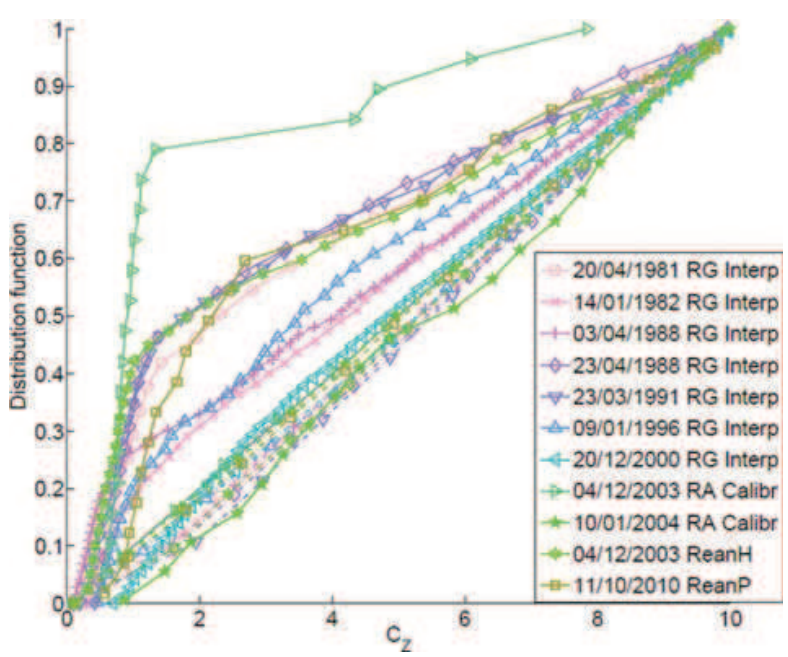

Fig. 12 Event posterior distribution functions, Salz at Cassaignes (solid line: behavioural simulations, dash-dot line: non-behavioural simulations). model. The results of the sensitivity analysis show that, on each catchment, the different events can present different shapes of posterior distribution functions for the same parameter, namely $C_{\mathrm{Z}}$. The methodology of event selection starts from the consideration that events with similar sensitivity to $C_{\mathrm{Z}}$ are likely to present similar averaged behaviours in terms of rainfall-to-runoff volume conservation. We therefore take into consideration the rainfall input leading to the a posteriori $C_{\mathrm{Z}}$ pdf closest to those of other events, i.e. producing comparable mean behaviour. Strong or extreme events regarding their peak flow are not used for SA and calibration but rather kept for validation. The procedure to select one rainfall product uses event sensitivity analysis (SA) with radar rainfall records (RA_Calibr) by default, other rainfall products (radar RA_ReanH, RA_ReanP or raingauges RG_Interp) are then 
considered if: (a) there are not enough behavioural simulations with RA_Calibr to perform a GSAGLUE analysis, and (b) one event presents a very dissimilar a posteriori $C_{\mathrm{Z}}$ pdf with respect to the other events. Indeed, for a given catchment, large dissimilarities between events for $C_{Z}$ sensitivity and unusual $C_{Z}$ values identified can be attributable to QPE errors under our hypothesis. While keeping such events for the calibration phase, we examine the other pdfs obtained from different rainfall types, if available for an event. However, all the events considered are not systematically simulated with all rainfall products, because of availability issues, for example.

Several rainfall products were selected with this method, especially in cases where unusual catchment behaviour were detected, for example:

- On the Tech catchment (Fig. 7(a)), pdfs from RA_Calibr show different sensitivities and resulting $C_{Z}$ values, whereas pdfs from RG_Interp show similar behaviour for the events of 24 February 2003, 4 April 2003 and 15 November 2005: the RG_Interp rainfall product of these three events was chosen for calibration.

- On the Têt catchment (Fig. 7(b)), for the events of 15 April 2004, 2 May 2004 and 28 January 2006, RG Interp and RA ReanH products were chosen as presenting similar behaviour.

Interpolated raingauge data (RG_Interp) can give good results in terms of Nash and $L_{\mathrm{NP}}$ and for pdf similarity in several cases. This may be attributable to raingauge density and locations that seem to capture enough rainfall variability for satisfactory flood modelling. The case of the event of 4 December 2003 on several catchments particularly highlights the problem. Different rainfall products were chosen for this event, according to the location of the considered catchment. On the Cesse (Fig. 8(a)) and the Agly (Fig. 10(b)), pdfs from RA_Calibr are consistent with pdfs of other events on the same catchment. On the Tech (Fig. 7(a)), RG_Interp gave pdfs with the greatest similarity to other events, while on the Salz (Fig. 12), the Lauquet (Fig. 11(b)) and the Orbiel (Fig. 9(b)), RA_ReanH provided the most similar pdfs. It seems that depending on the location of the catchment with respect to the radar, rainfall variability is not always well captured by the same rainfall product. As already mentioned, for the Tech and Têt catchments, raingauges give better results than radar data, maybe because they are the catchments at the greatest distance from the radar. In addition, high-relief topography with deep narrow valleys may disturb radar measurements.

However, pdf similarity does not exclude various hydrological behaviours for a particular catchment. For example, both small events and strong events that certainly activate different flow paths and runoff formation dynamics within a catchment, can present similar pdfs, as for 15 November 2005 for the Verdouble $\left(3.3 \mathrm{~m}^{3} \mathrm{~s}^{-1} \mathrm{~km}^{-2}\right)$ and the Orbieu $\left(2.65 \mathrm{~m}^{3} \mathrm{~s}^{-1} \mathrm{~km}^{-2}\right)$ or 2 December 1987 for the Cesse $\left(2 \mathrm{~m}^{3} \mathrm{~s}^{-1} \mathrm{~km}^{-2}\right)$. This is true for catchments that are both sensitive and less sensitive to $C_{\mathrm{Z}}$. As a result we do not exclude various catchment behaviours that can be caused by different rainfall spatio-temporal variability.

The method enabled us to select a rainfall product on almost all the catchments (Table 5). However the selection was particularly difficult on the Orbieu catchment for which it seems impossible to identify a mean behaviour (Fig. 11(a)). Altogether, the selection has been more difficult for the catchments for which the behavioural simulations were for $C_{Z}$ close to 1 and easier for catchments for which the behavioural simulations were for greater $C_{Z}$ values.

Different sensitivity and calibrated values of the $C_{\mathrm{Z}}$ coefficient between catchments can indicate different rainfall-to-runoff volume conservation relations for catchments. The pdf analysis is applicable to different rainfall types such as radar or interpolated raingauge data, as results can attest. It seems that Opoul radar rainfall data quality is quite variable in time and space with QPE errors sometimes significantly affecting hydrological modelling sensitivity and performance.

\section{CALIBRATION OF CATCHMENT PARAMETER SETS WITH SELECTED RAINFALL EVENTS}

To perform real time predictions and regionalization, one parameter set per catchment may be required. The objective of this section is two-fold: to document the difficult problem of calibration for flash-flood event models with results performed for three medium-sized catchments, Salz, Tech and Verdouble (144-299 $\mathrm{km}^{2}$ ), areas located on contrasting bedrocks, and showing the benefit of selecting the right rainfall dataset. Several events and rainfall data types were selected with the SA method presented above.

Here, we use an optimization technique over several calibration flood events considered together. Calibration is performed using a BFGS minimization algorithm (Broyden-Fletcher-Goldfarb-Shanno) called 
M2QN1 (Lemaréchal and Panier 2000) with a sum of square error (SSE) cost function. The five sensitive parameters of the MARINE model are calibrated for five random starting points in the parameter ranges (Table 6). This multiple direction optimization algorithm is used both for calibration and real time variational data assimilation within the MARINE model (Castaings et al. 2009). The $L_{\mathrm{NP}}$ would be suitable for a multi-objective calibration, but its implementation requires additional observation data. The aim here is not to discuss the calibration method, which often converges on the same parameter combination from different starting points in the parameter space, but to illustrate the usefulness of pdf selection for rainfall analysis.

The calibration leads to satisfactory Global Nash efficiencies of around 0.9 for complete sets (Table 7), and peak simulation errors below $30 \%$, which is reasonable in the case of flash floods (Figs 13-15). Validations are presented on one event for each catchment, and (Nash, $L_{\mathrm{NP}}$ ) efficiencies range from $(0.61,0.7)$ for Salz to $(0.89,0.87)$ for Verdouble (Table 7). It should be noted that validation efficiencies are fairly close to calibration efficiencies.

The example of the 15 March 2011 event on the Tech illustrates the benefits of this method. Indeed the $C_{Z}$ pdf of this 15 March 2011 (RA_Calibr) event on the Tech was not similar to the other pdfs and suggested that QPE was underestimated, as confirmed by validation (Fig. 16) and the runoff coefficient (Table 7). Single calibration for this event give $\mathrm{C}_{\mathrm{Z}}$ values around 2.5. In validation with the calibrated parameter set of Table 7, peak flow is underestimated by about $40 \%$ (Fig. 16, right). Considering (RG_Interp) rainfalls, the peak flow underestimation is smaller, at about $15 \%$ (Fig. 14).

A larger $C_{Z}$ parametric compensation $\left(C_{Z}=4.34\right)$ is required for the Tech catchment, while the two other catchments need $\mathrm{C}_{Z} \approx 1$ (Table 7). Initial and maximal soil saturations are comparable for the three catchments and the soil data (pedology) from the BD-sol give a mean soil thickness of 0.31 and $0.33 \mathrm{~m}$ for the Salz and Verdouble, respectively, and $0.16 \mathrm{~m}$ for the Tech (Table 1). So catchment storage capacity has to be increased by a factor of 2 or more for the granite and primary era altered substrates, as for the Tech or Têt catchments.

The calibration procedure leads to relatively low main channel $K_{\mathrm{D} 1}$ and overbank $K_{\mathrm{D} 2}$ roughness, i.e. significant friction is necessary to delay the flow. This might be due to water partition, with a surplus drained quickly with surface runoff on hillslopes and in the drainage network. Subsurface lateral transfer tends to be slower. This indicates that water distribution between lateral flow components and other mechanisms, such as exfiltration in the drainage network, and its representation need to be improved. Measurements at different scales are still necessary to better constrain these flow dynamics.

Maps of maximum soil moisture deficit are plotted for Tech and Verdouble validation events (Fig. 17). Nearly the whole Verdouble catchment is saturated at $10 \mathrm{~h}$, just before peak time, whereas, for the Tech, several areas close to the main drain and the middle of the catchment have a minimum deficit of $27 \%$. Peak flow underestimation on the Tech catchment might be explained by underdevelopment of contributing areas mainly because of rainfall underestimation and location errors (Fig. 14(b)). The possibility of mapping state variables (Fig. 17) is interesting to compare, for example, the development of the extent of contributing areas for typical soil configurations.

\section{CONCLUSION}

The 11 catchment headwaters of the eastern Pyrenees foothills, with areas ranging from 36 to $776 \mathrm{~km}^{2}$, are interesting study sites for flash-flood generating mechanisms, given the quantity of static, meteorological and hydrometric data available. They present contrasting physical properties and behaviours that can be detected with the help of statistics (Garambois et al. 2011).

Global sensitivity analysis of the MARINE model is performed on each event for a catchment given various flood responses. MARINE model formulation was found to be an appropriate tool for flash-flood modelling with various rainfall data types, even for small catchments, as the number of event simulations eligible for GSA-GLUE can attest. Global mean behaviours are identified for each catchment and differences between catchment sensitivity and parameterization for the water balance parameter $C_{Z}$ can be attributed to deep percolation in altered bedrock, as suggested by other authors (Castaings et al. 2009, Roux et al. 2011). Indeed, catchments needing a larger $C_{\mathrm{Z}}$ value present substrates that develop on granite, schist and primary era formations and that seem to present the highest bedrock storage as shown by Vannier et al. (2014) with recession analysis in the Cévennes-Vivarais region. This may be due to the fact that the soil depth used in 

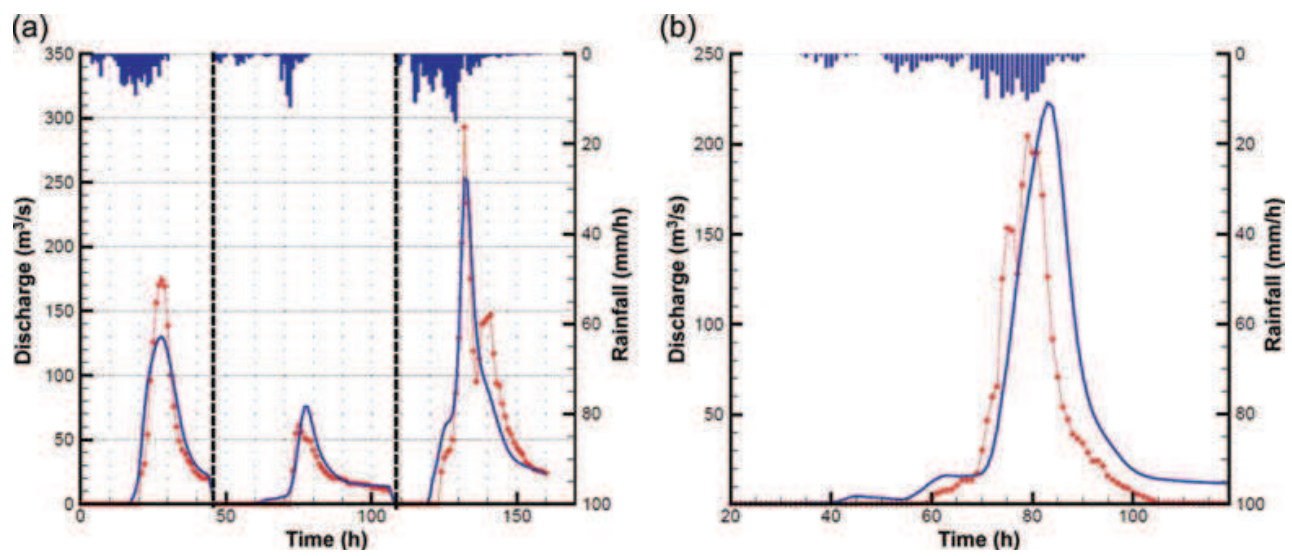

Fig. 13 Salz catchment $\left(144 \mathrm{~km}^{2}\right.$ ): (a) calibration (blue solid line) and observed discharge (red dotted line) over three different flood events, 4 December 2003 (RA_ReanH), 10 January 2004 (RA_Calibr), 11 October 2010 (RA_Calibr); and (b) parameter set validation for 23 December 2000 (RG_Interp).
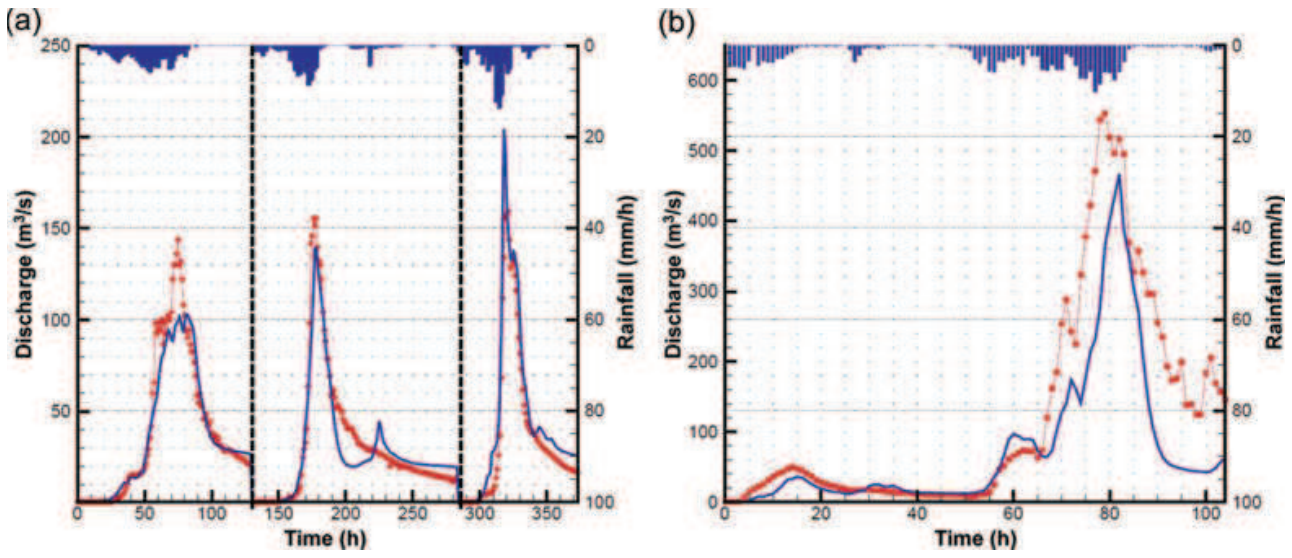

Fig. 14 Tech catchment $\left(250 \mathrm{~km}^{2}\right.$ ): (a) calibration (blue solid line) and observed discharge (red dotted line) over three different flood events, 24 February 2003 (RG_Interp), 4 December 2003 (RG_Interp), 15 November 2005 (RG_Interp); and (b) parameter set validation for 15 March 2011 (RG_Interp).

(a)

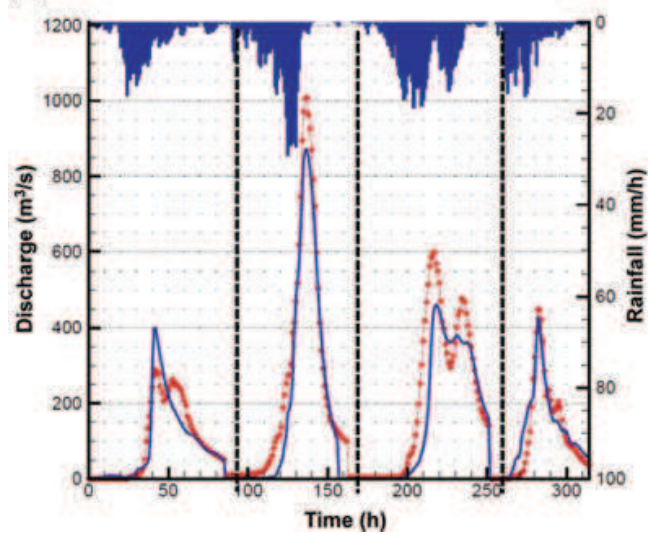

(b)

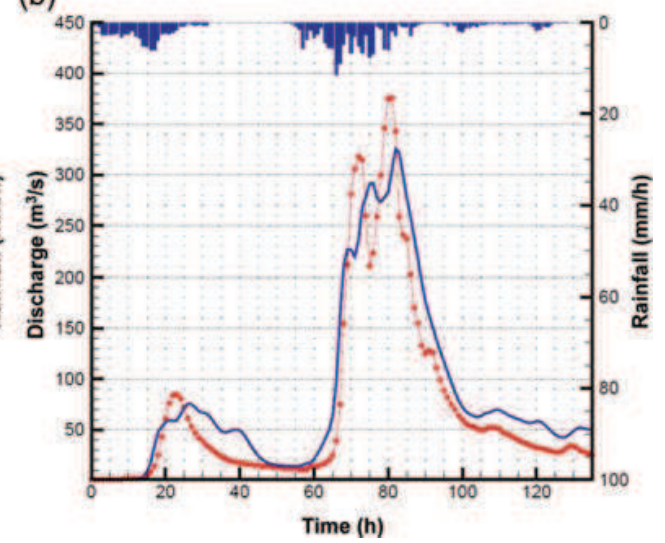

Fig. 15 Verdouble catchment $\left(299 \mathrm{~km}^{2}\right.$ ): (a) calibration (blue solid line) and observed discharge (red dotted line) over four different flood events, 11 April 2002 (RA Calibr), 15 November 2005 (RA_Calibr), 28 January 2006 (RA Calibr), 10 October 2010 (RA_Calibr); and (b) parameter set validation for 15 March $20 \overline{1} 1$ (RA_ReanP). 
(a)

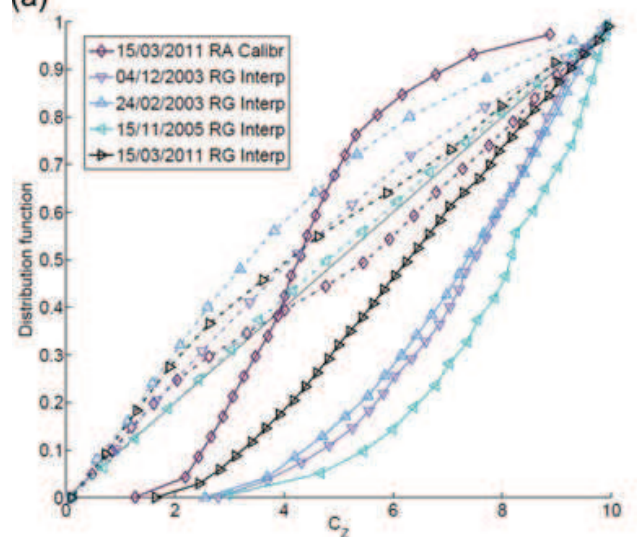

(b)

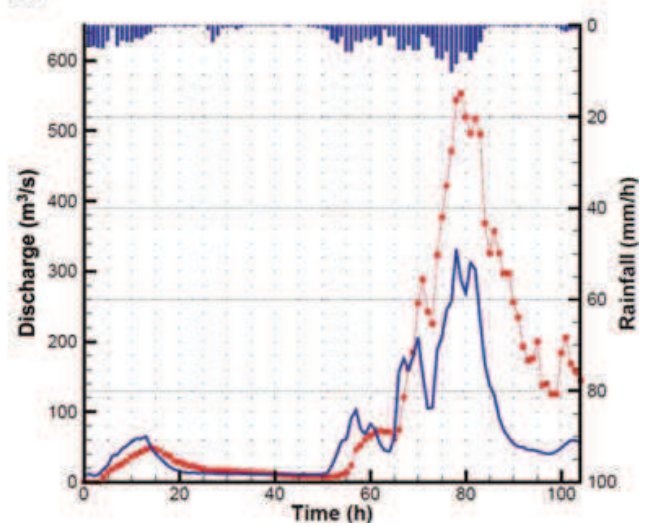

Fig. 16 Tech at Pas du Loup: (a) event posterior distribution function, and (b) calibrated parameter set test (blue solid line) and observed discharge (red dotted line) for 15 March 2011 (RA_Calibr).

(a)

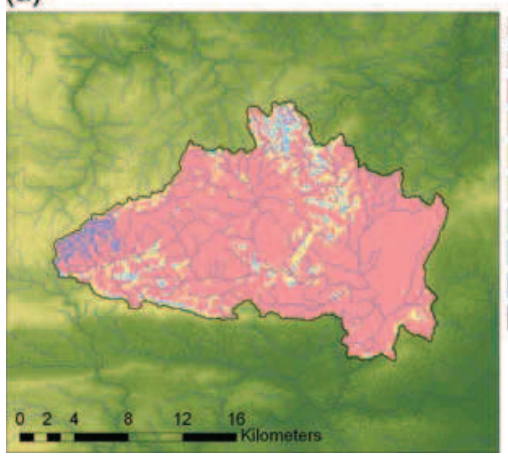

DSS_03/15 at 10h Moisture deficit (\%) 0-2 $2.1-5.9$ $6-9.8$ $9.9-14$
$15-17$ $18-21$ ए $22-26$

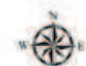

(b)

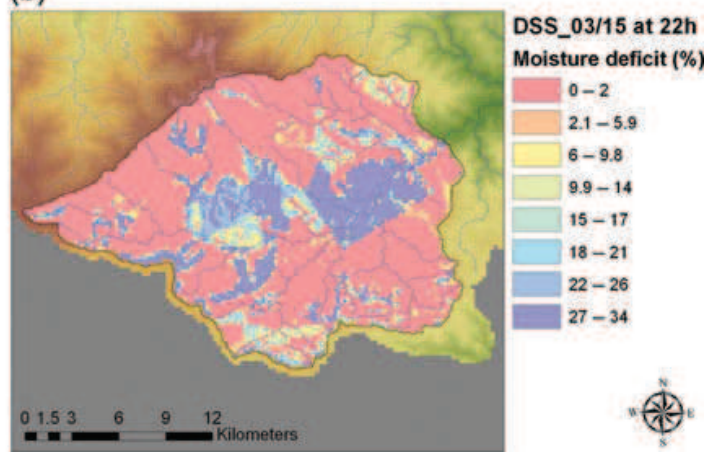

Fig. 17 Maximum soil saturation for the 15 March 2011 event: (a) Verdouble at Tautavel at $10 \mathrm{~h}$, and (b) Tech at Pas du Loup at $22 \mathrm{~h}$.

modelling only takes soil horizons A (surface soil) and B (subsoil) into account. Horizons C (parent rock) and $\mathrm{R}$ (bedrock) are not taken into account even though they may be hydrologically active.

Moreover, the sensitivity of the soil thickness multiplicative constant controlling the water balance of the MARINE model enables the selection of rainfall input with respect to an identified catchment behaviour. This method was seen to be useful in this study for rainfall product selection on some catchments, whereas it can be difficult to choose between two rainfall products with a direct comparison, as shown in Section 2.1. Among the possible reasons for the fluctuating quality of the data there might be the lumpy topography, the readjustment procedure or the position of the radar, which can cause wet radome situations or other sources of attenuation.
The method proposed here is applicable for any conservative hydrological model with an explicit storage parameter. Model calibration with the selected events was performed using the MARINE model. Multiple event calibration and validation give performances ranging from 0.7 to 0.89 . For model calibration, it is useful to understand how to parameterize soil volume (and thus storage capacity) for several types of substrates/bedrocks. Moreover, good calibration and validation efficiencies with a soil similarity approach are an interesting basis for flash flood prediction at ungauged locations with a distributed model. Indeed, this calibration process aims at finding a mean physical behaviour through flood water balance for each catchment which can be interesting for transferring parameter sets to ungauged catchments with respect to physiographic descriptors of the catchment for example. 
Acknowledgements The authors gratefully acknowledge data supply by the French central flood forecasting service, $\mathrm{SCHAPI}^{3}$ and the regional flood forecasting service, SPCMO.

Funding The authors gratefully acknowledge the financial support of the SCHAPI.

\section{REFERENCES}

Andréassian, V., et al., 2001. Impact of imperfect rainfall knowledge on the efficiency and the parameters of watershed models. Journal of Hydrology, 250 (1-4), 206-223. doi:10.1016/ S0022-1694(01)00437-1

Aronica, G., Bates, P.D., and Horritt, M.S., 2002. Assessing the uncertainty in distributed model predictions using observed binary pattern information within GLUE. Hydrological Processes, 16 (10), 2001-2016. doi:10.1002/hyp.398

Aronica, G., Hankin, B., and Beven, K., 1998. Uncertainty and equifinality in calibrating distributed roughness coefficients in a flood propagation model with limited data. Advances in Water Resources, 22 (4), 349-365. doi:10.1016/S03091708(98)00017-7

Ayral, P.A., et al., 2007. Forecasting flash floods with an operational model. Advances in Natural and Technological Hazards Research, 25, 335-352.

Bárdossy, A. and Das, T., 2008. Influence of rainfall observation network on model calibration and application. Hydrology and Earth System Sciences, 12, 77-89. doi:10.5194/hess12-77-2008

Beven, K., 2006. A manifesto for the equifinality thesis. Journal of Hydrology, 320 (1-2), 18-36. doi:10.1016/j.jhydrol.2005.07.007

Beven, K.J. and Binley, A.M., 1992. The future of distributed models: model calibration and uncertainty prediction. Hydrological Processes, 6, 279-298.

Beven, K.J., 2002. Rainfall-runoff modelling: the Primer. Chichester: John Wiley \& Sons, LTD.

Beven, K.J., Smith, P.J., and Freer, J.E., 2008. So just why would a modeller choose to be incoherent? Journal of Hydrology, 354 (1-4), 15-32. doi:10.1016/j.jhydrol.2008.02.007

Blazkova, S. and Beven, K., 2009. A limits of acceptability approach to model evaluation and uncertainty estimation in flood frequency estimation by continuous simulation: Skalka catchment, Czech Republic. Water Resources Research, 45 (12), W00B16. doi:10.1029/2007WR006726

Blöschl, G., 2005. Rainfall-runoff modelling of ungauged catchments. In: M.G. Anderson, ed., Encyclopedia of hydrological sciences. Chichester: John Wiley \& Sons, 2061-2080.

Borga, M., et al., 2008. Surveying flash floods: gauging the ungauged extremes. Hydrological Processes, 22 (18), 38833885. doi:10.1002/hyp.7111

Braud, I., et al., 2010. The use of distributed hydrological models for the Gard 2002 flash flood event: analysis of associated hydrological processes. Journal of Hydrology, 394 (1-2), 162-181. doi:10.1016/j.jhydrol.2010.03.033

Castaings, W., et al., 2009. Sensitivity analysis and parameter estimation for distributed hydrological modeling: potential of variational methods. Hydrology and Earth System Sciences J1 HESS, 13 (4), 503-517. doi:10.5194/hess-13-503-2009

Choi, H.T. and Beven, K., 2007. Multi-period and multi-criteria model conditioning to reduce prediction uncertainty in an application of TOPMODEL within the GLUE framework.
Journal of Hydrology, 332 (3-4), 316-336. doi:10.1016/j. jhydrol.2006.07.012

Costa, J.E., 1987. Hydraulics and basin morphometry of the largest flash floods in the conterminous United States. Journal of Hydrology, 93 (3-4), 313-338. doi:10.1016/0022-1694(87) 90102-8

Creutin, J.-D. and Borga, M., 2003. Radar hydrology modifies the monitoring of flash-flood hazard. Hydrological Processes, 17 (7), 1453-1456. doi:10.1002/hyp.5122

Davolio, S., Buzzi, A., and Malguzzi, P., 2009. Orographic triggering of long lived convection in three dimensions. Meteorology and Atmospheric Physics, 103 (1-4), 35-44. doi:10.1007/s00703008-0332-5

Delrieu, G., et al., 2014. Dependance of radar quantitative precipitation estimation error on the rain intensity in the Cévennes region, France. Hydrological Sciences Journal, special issue: Weather radar and hydrology, 59 (7), 1308-1319. doi:10.1080/ 02626667.2013.827337

Duan, Q., Sorooshian, S., and Gupta, V.K., 1992. Effective and efficient global optimization for conceptual rainfall-runoff models. Water Resources Research, 28 (4), 1015-1031. doi:10.1029/91WR02985

Freer, J., Beven, K.J., and Ambroise, B., 1996. Bayesian estimation of uncertainty in runoff prediction and the value of data: an application of the GLUE approach. Water Resources Research, 32 (7), 2161-2173. doi:10.1029/95WR03723

Gaál, L., et al., 2012. Flood timescales: understanding the interplay of climate and catchment processes through comparative hydrology. Water Resources Research, 48 (4), W04511. doi:10.1029/2011WR011509

Garambois, P.A., et al., 2011. Relations between streamflow indices, rainfall characteristics and catchment physical descriptors for flash flood events. In: R.J. Moore, S.J. Cole and A.J. Illingworth, eds. Weather radar and hydrology. (Proceedings of a symposium held in Exeter, UK, April 2011). Wallingford: International Association of Hydrological Sciences, IAHS Publ. 351, 581-586.

Garambois, P.A., et al., 2013. Characterization of process-oriented hydrologic model behavior with temporal sensitivity analysis for flash floods in Mediterranean catchments. Hydrology and Earth System Sciences, 17, 2305-2322. doi:10.5194/hess17-2305-2013

Garambois, P.A., et al., 2014. Analysis of flash flood-triggering rainfall for a process-oriented hydrological model. Atmospheric Research., 137, 14-24. doi:10.1016/j.atmosres. 2013.09.016

Gaume, E., et al., 2004. Hydrological analysis of the river Aude, France, flash flood on 12 and 13 November 1999. Journal of Hydrology, 286 (1-4), 135-154. doi:10.1016/j.jhydrol. 2003.09.015

Georgakakos, K.P., 1992. Advances in forecasting flash floods. Proceedings of the CNAA-AIT Joint seminar on prediction and damage mitigation of meteorologicaly induced Natural disasters, 21-24 May, National Taïwan University, Taipei, 280-293.

Gupta, H., et al., 2003. Reply to comment by K. Beven and P. Young on Bayesian recursive parameter estimation for hydrologic models. Water Resources Research, 39 (5), 1117. doi:10.1029/2002WR001405

Habets, F., et al., 2008. The SAFRAN-ISBA-MODCOU hydrometeorological model applied over France. Journal of Geophysical Research, 113, D06113. doi:10.1029/2007JD008548

Hornberger, G.M. and Spear, R.C., 1981. An approach to the preliminary analysis of environmental systems. Journal of Environmental Management, 12, 7-18. 
Jin, X., et al., 2010. Parameter and modeling uncertainty simulated by GLUE and a formal Bayesian method for a conceptual hydrological model. Journal of Hydrology, 383 (3-4), 147155. doi:10.1016/j.jhydrol.2009.12.028

Johnston, P.R. and Pilgrim, D.H., 1976. Parameter optimization for watershed models. Water Resources Research, 12 (3), 477486. doi:10.1029/WR012i003p00477

Kavetski, D., Kuczera, G., and Franks, S.W., 2006. Bayesian analysis of input uncertainty in hydrological modeling: 1 . Theory. Water Ressources Research, 42 (3), W03407.

Kirstetter, P.-E., et al., 2010. Toward an error model for radar quantitative precipitation estimation in the Cévennes-Vivarais region, France. Journal of Hydrology, 394 (1-2), 28-41. doi:10.1016/j.jhydrol.2010.01.009

Krajewski, W.F. and Smith, J.A., 2002. Radar hydrology: rainfall estimation. Advances in Water Resources, 25 (8-12), 13871394. doi:10.1016/S0309-1708(02)00062-3

Kuczera, G. and Parent, E., 1998. Monte Carlo assessment of parameter uncertainty in conceptual catchment models: the Metropolis algorithm. Journal of Hydrology, 211, 69-85. doi:10.1016/S0022-1694(98)00198-X

Le Lay, M. and Saulnier, G.M., 2007. Exploring the signature of climate and landscape spatial variabilities in flash flood events: case of the 8-9 September 2002 Cévennes-Vivarais catastrophic event. Geophysical Research Letters, 34, L13401. doi:10.1029/2007GL029746.

Lee, Y.H. and Singh, V.P., 1998. Application of the Kalman filter to the Nash model. Hydrological Processes, 12, 755767. doi:10.1002/(SICI)1099-1085(19980430)12:5<755::AIDHYP623>3.0.CO;2-\#

Lemaréchal, C. and Panier, E., 2000. les modules M2QN1 et MQHESS, INRIA.

Li, L., et al., 2010. Evaluation of the subjective factors of the GLUE method and comparison with the formal Bayesian method in uncertainty assessment of hydrological models. Journal of Hydrology, 390 (3-4), 210-221. doi:10.1016/j.jhydrol. 2010.06 .044

Looper, J.P. and Vieux, B.E., 2012. An assessment of distributed flash flood forecasting accuracy using radar and rain gauge input for a physics-based distributed hydrologic model. Journal of Hydrology, 412-413, 114-132. doi:10.1016/j. jhydrol.2011.05.046

Maidment, D.R., 1992. Handbook of Hydrology. New York: McGraw-Hill.

Mantovan, P. and Todini, E., 2006. Hydrological forecasting uncertainty assessment: incoherence of the GLUE methodology. Journal of Hydrology, 330 (1-2), 368-381. doi:10.1016/j. jhydrol.2006.04.046

Manus, C., et al., 2009. A modeling approach to assess the hydrological response of small mediterranean catchments to the variability of soil characteristics in a context of extreme events. Hydrology and Earth System Sciences J1 - HESS, 13 (2), 7997. doi:10.5194/hess-13-79-2009

Merz, R. and Blöschl, G., 2004. Regionalisation of catchment model parameters. Journal of Hydrology, 287 (1-4), 95-123. doi:10.1016/j.jhydrol.2003.09.028

Meselhe, E.A., et al., 2009. Sensitivity of conceptual and physically based hydrologic models to temporal and spatial rainfall sampling. Journal of Hydrologic Engineering, 14 (7), 711-720. doi:10.1061/(ASCE)1084-0699(2009)14:7(711)

Moulin, L., Gaume, E., and Obled, C., 2009. Uncertainties on mean areal precipitation: assessment and impact on streamflow simulations. Hydrology and Earth System Sciences Discussions, 13 (2), 99-114. doi:10.5194/hess-13-99-2009

Nou, A., et al., 2011. Evidence of an early phreatic and confined karst phase in Minervois, South of France. In: Andreo et al. eds.
Advances in Research in Karst Media: Environmental Earth Sciences. Berlin: Springer, 63-68.

O'Connor, J.E. and Costa, J.E., 2004. Spatial distribution of the largest rainfall-runoff floods from basins between 2.6 and $26,000 \mathrm{~km}^{2}$ in the United States and Puerto Rico. Water Resources Research, 40 (1), W01107.

Oudin, L., et al., 2006. Impact of biased and randomly corrupted inputs on the efficiency and the parameters of watershed models. Journal of Hydrology - the Model Parameter Estimation Experiment - MOPEX, 320 (1-2), 62-83.

Pushpalatha, R., et al., 2011. A downward structural sensitivity analysis of hydrological models to improve low-flow simulation. Journal of Hydrology, 411 (1-2), 66-76. doi:10.1016/j. jhydrol.2011.09.034

Quintero, F., et al., 2012. A scenario-incorporating analysis of the propagation of uncertainty to flash flood simulations, Journal of Hydrology, 460-461, 90-102.

Rawls, W.J. and Brakensiek, D.L., 1985. Prediction of soil water properties for hydrologic modelling. Watershed management in the eighties. Proceedings of the American Society of Civil Engineers symposium, Denver, 30 April-1 May. New York, NY: ASCE, 293-299.

Robbez-Masson, J.-M., et al., 2002. A regional multimedia soil and landscape database on the web in order to help use and teaching of soil data. 17th World congress of Soil Science, 14-21 August, Bangkok.

Roux, H., et al., 2011. A physically-based parsimonious hydrological model for flash floods in Mediterranean catchments. Natural Hazards and Earth System Sciences J1 - NHESS, 11 (9), 2567-2582. doi:10.5194/nhess-11-2567-2011

Seity, Y., et al., 2011. The AROME-France convective-scale operational model. Monthly Weather Review, 139 (3), 976-991. doi:10.1175/2010MWR3425.1

Tabary, P., 2007. The new French operational radar rainfall product. Part I: methodology. Weather and Forecasting, 22 (3), 393408. doi:10.1175/WAF1004.1

Tabary, P., et al., 2007. The new French operational radar rainfall product. Part II: validation. Weather and Forecasting, 22 (3), 409-427. doi:10.1175/WAF1005.1

Tang, Y., et al., 2007. Advancing the identification and evaluation of distributed rainfall-runoff models using global sensitivity analysis. Water Resources Research, 43 (6), W06415. doi:10.1029/ 2006WR005813

Tarolli, P., et al., 2012. Analysis of flash flood regimes in the North-Western and South-Eastern Mediterranean regions. Natural Hazards Earth Systems Sciences, 12, 1255-1265. doi:10.5194/nhess-12-1255-2012

Todini, E., 2007. Hydrological catchment modelling: past, present and future. Hydrology and Earth System Sciences J1 - HESS, 11 (1), 468-482. doi:10.5194/hess-11-468-2007

Tramblay, Y., et al., 2010. Assessment of initial soil moisture conditions for event-based rainfall-runoff modelling. Journal of Hydrology, 387 (3-4), 176-187. doi:10.1016/j.jhydrol.2010. 04.006

Tramblay, Y., et al., 2011. Impact of rainfall spatial distribution on rainfall-runoff modelling efficiency and initial soil moisture conditions estimation. Natural Hazards and Earth System Sciences, 11 (1), 157-170. doi:10.5194/nhess-11-157-2011

Vannier, O., Braud, I., and Anquetin, S., 2014. Regional estimation of catchment-scale soil properties by means of streamflow recession analysis for use in distributed hydrological models. Hydrological Processes, 28 (26), 6276-6291. doi:10.1002/ hyp. 10101

Versini, P.A., 2012. Use of radar rainfall estimates and forecasts to prevent flash flood in real time by using a road inundation warning system. Journal of Hydrology, 416-417, 157-170. 
Viglione, A., et al., 2010. Quantifying space-time dynamics of flood event types. Journal of Hydrology, 394 (1-2), 213-229. doi:10.1016/j.jhydrol.2010.05.041

Vincendon, B., et al., 2010. Benefit of coupling the ISBA land surface model with a TOPMODEL hydrological model version dedicated to Mediterranean flash-floods. Journal of Hydrology, 394 (1-2), 256-266. doi:10.1016/j.jhydrol. 2010.04.012

Vincendon, B., et al., 2011. Perturbation of convection-permitting NWP forecasts for flash flood ensemble forecasting. Natural Hazards Earth Systems Sciences, 11, 1529-1544. doi:10.5194/ nhess-11-1529-2011

Vrugt, J., et al., 2009. Equifinality of formal (DREAM) and informal (GLUE) Bayesian approaches in hydrologic modeling?. Stochastic Environmental Research and Risk Assessment, 23 (7), 1011-1026. doi:10.1007/s00477-008-0274-y

Vrugt, J.A., et al., 2003. Effective and efficient algorithm for multiobjective optimization of hydrologic models. Water Resources Research, 39 (8), 1214. doi:10.1029/2002WR001746

Wagener, T., et al., 2003. Towards reduced uncertainty in conceptual rainfall-runoff modelling: dynamic identifiability analysis. Hydrological Processes, 17 (2), 455-476. doi:10.1002/hyp.1135

Wagener, T., Wheater, H., and Gupta, H., 2004. Rainfall-runoff modelling in gauged and ungauged catchments. London: Imperial College Press.

Weingartner, R., Barben, M., and Spreafico, M., 2003. Floods in mountain areas - an overview based on examples from
Switzerland. Journal of Hydrology, 282 (1-4), 10-24. doi:10.1016/S0022-1694(03)00249-X

Werner, M., 2004. Spatial flood extent modelling. A performancebased comparison. Thesis (PhD), Delft University of Technology, Delft.

Xu, C.-Y., et al., 2006. Evaluation of seasonal and spatial variations of lumped water balance model sensitivity to precipitation data errors. Journal of Hydrology, 324 (1-4), 80-93. doi:10.1016/j. jhydrol.2005.09.019

Yakir, H. and Morin, E., 2011. Hydrologic response of a semi-arid watershed to spatial and temporal characteristics of convective raincells. Hydrology and Earth System Sciences, 15, 393-404. doi:10.5194/hess-15-393-2011

Yang, J., 2011. Convergence and uncertainty analyses in MonteCarlo based sensitivity analysis. Environmental Modelling \& Software, 26 (4), 444-457. doi:10.1016/j.envsoft.2010.10.007

Yang, J., et al., 2008. Comparing uncertainty analysis techniques for a SWAT application to the Chaohe Basin in China. Journal of Hydrology, 358 (1-2), 1-23. doi:10.1016/j.jhydrol.2008.05.012

Zin, I., 2002. Incertitudes et ambiguités dans la modélisation hydrologique. Discussion, développements méthodologiques et application à l'hydrologie de crue en Ardèche. Thesis (Thèse de Doctorat), INPG, Grenoble.

Zoccatelli, D., et al., 2011. spatial moments of catchment rainfall: rainfall spatial organisation, basin morphology, and flood response. Hydrology and Earth System Sciences, 15, 37673783. doi:10.5194/hess-15-3767-2011 